



\section{THE NANTICOKE COMMUNITY OF DELAWARE}

BY

FRANK G. SPECK

Contents

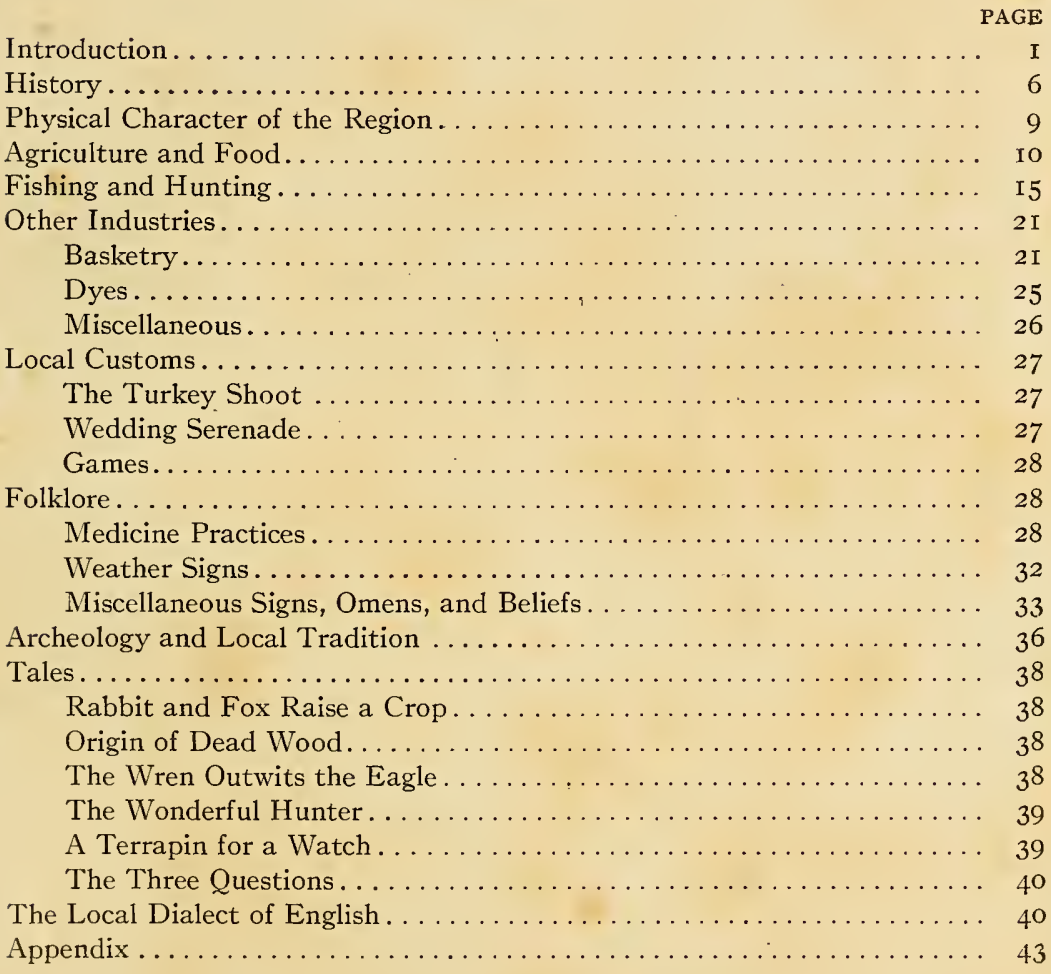

\section{INTRODUCTION}

URING each winter and spring since I9I I I have spent as much time as was available in ethnologic work among the mixed-blood descendants of the Nanticoke Indians living in several communities in southern Delaware. Dr W. D. Wallis, at the instance of the University Museum, University of Penn- 


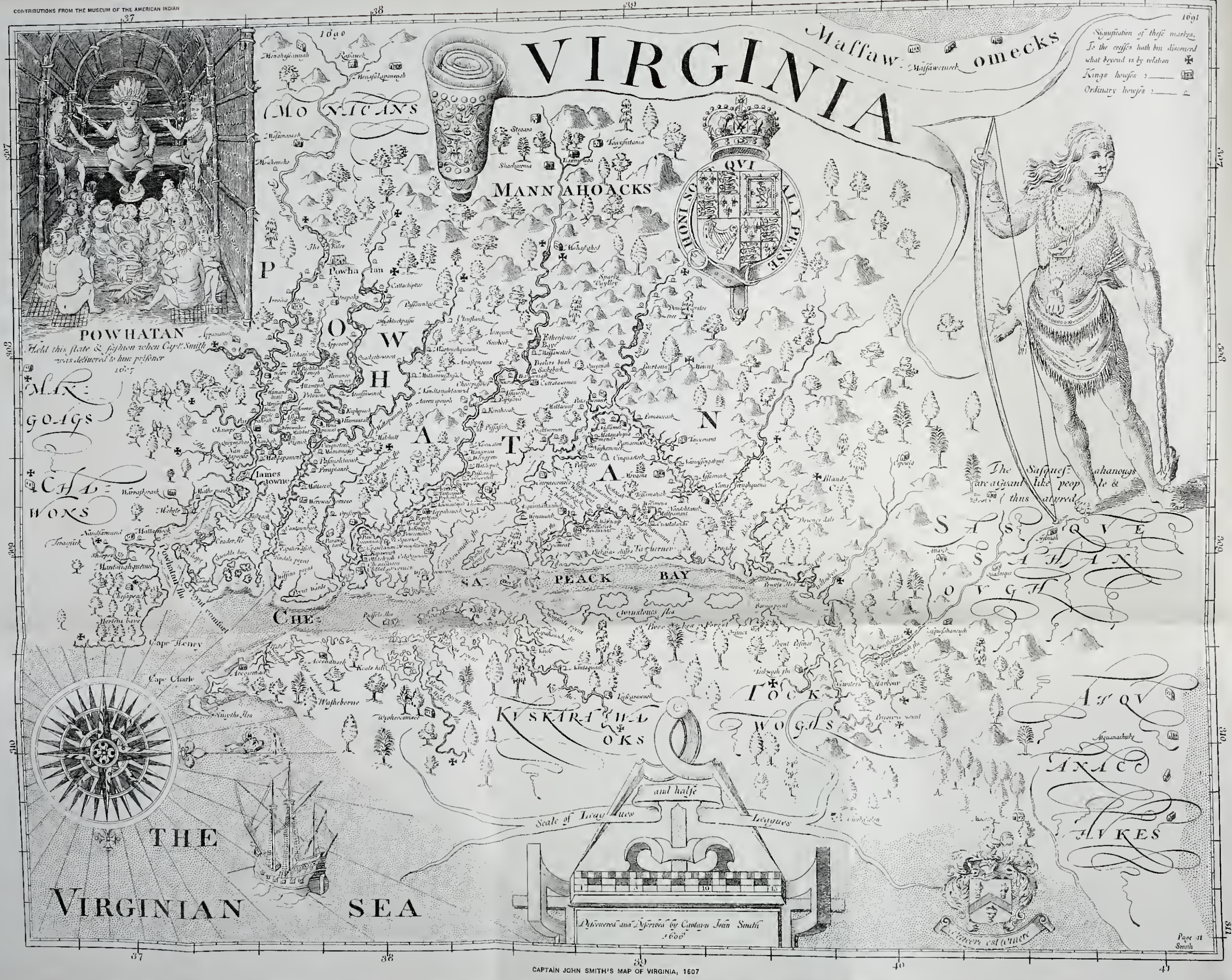



sylvania, also had a share in the commencement of this investigation. These people, who occasionally have been reported in papers and journals, ${ }^{1}$ form two bands, the nuclear band living in Indian River Hundred, Sussex county, the other, supposedly an offshoot, residing at Cheswold, Kent county. The members of the bands together are roughly estimated to number about 70o. These people form self-recognized communities, with their own schools and churches, and possess a decidedly endogamous tendency which refuses particularly to recognize marriage with negroes. They style themselves variously "Nanticokes," "Moors," and "Indians." This feeling of local seclusiveness is a marked trait among these people and was noted by Babcock who visited the tribe in I 899 and wrote a short but interesting account of what he saw. ${ }^{2}$

Physically the community exhibits a great lack of racial homogeneity, the types of physiognomy, color, and hair ranging from the European, the mulatto, and the Indian through all the usual gradations. Some individuals have straight hair, fair skin, and blue eyes; some have brown skin and kinky or curly hair; others have broad faces and straight, black hair, the color and general appearance of Indians. It is common to find these characteristics divided irregularly among the members of the same family.

An interesting tradition current among the members of the band is that they are descended from a crew of Moorish sailors who

${ }^{1}$ See James Mooney, "Siouan Tribes of the East," Bulletin 22, Bureau of American Ethnology, pp. I2, 51, 80, Washington, I895. Mooney, "The Powhatan Confederacy, Past and Present," American Anthropologist, I907, vol. IX, pp. I29-I52. Encyclopædia Britannica, Eleventh ed. (I9I0-II), p. 948, article "Delaware." "In Indian River Hundred there lived a community of people-many of whom are of the fair Caucasian type-called 'Indians' or 'Mloors': they are now quite generally dispersed throughout the State, especially in Kent and Sussex counties. Their origin is unknown, but according to local tradition they are the descendants of some Moorish sailors who were cast ashore many years ago in a shipwreck; their own tradition is that they are descended from an Irish mother and a negro father, these children having intermarried with Indians of the Nanticoke tribe. They have where practicable separate churches and schools, the latter receiving state aid." Brinton, The Lenâpé and their Legends, p. 22-25, Phila., I885, gives a review of Nanticoke history and some notes on their ethnology.

${ }^{2}$ William H. Babcock, "The Nanticoke Indians of Indian River, Delaware," American Anthropologist, n. s., I 899, vol. I, pp. 277-282. The author does not give any ethnological information, but he describes the appearance of the people. 

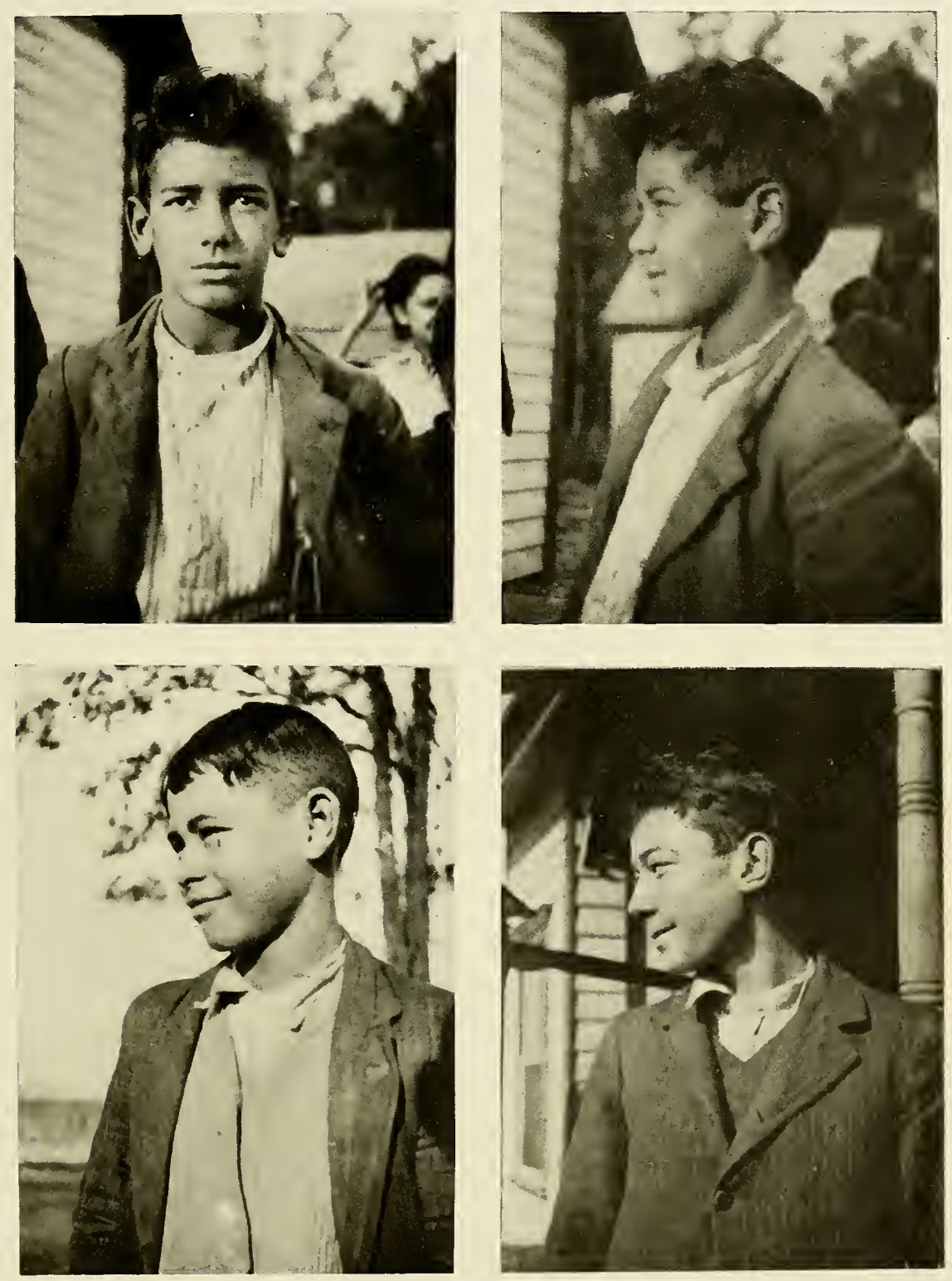

NANTICOKE TYPES

(the upper portraits are full-Face and profile of the same boy) 

were shipwrecked near Indian River inlet, escaped to the shore, and intermarried with the Indians who were living there. This story is well known in the region and is repeated with several variations. One states that on board the wrecked vessel was an Irish princess; another claims that the vessel was owned by a Moorish prince; another that the Moors were pirates from the Spanish main, and to this they attribute their local name of "Moors." As important as this story seems to be, I was unable to secure any consecutive version worth recording as testimony in the words of the narrator. Those who know of it give only the general facts as mentioned above. A few discredit the story altogether. On the whole, however, I am inclined to credit the general claim that Moorish sailors might have been shipwrecked on the treacherous shoals off the southern Delaware coast and come ashore to the shelter of the Indian natives. When this might have happened it is difficult to say, unless we assume that it was during the years of piracy on the high seas in the seventeenth and the early part of the eighteenth century (I650-I 720 approximately). The importance of the term "Moors" in connection with the pirates of the West Indies suggests relationship in this case. (See Appendix.)

As may be observed in the portraits accompanying this paper ( $\mathrm{pl}$. $\mathrm{II}-\mathrm{XI}$ ) the appearance of even the most negroid of these people is quite different from that of the common Southern negro type. They are much more refined in appearance, with thinner lips and narrower noses. Heckewelder ${ }^{1}$ says that the Nanticoke were distinguished from neighboring tribes by a darker color. Writing at this date, if we assume the story of the Moorish admixture to have some foundation in truth, one does not have to seek far for an explanation of the dark complexion of the Nanticoke. ${ }^{2}$ It would seem that the tribe bore evidence of an African admixture before leaving Maryland, which would be before $\mathbf{1} 748$, at the latest. The "Moor"

1 J. G. E. Heckewelder, An Account of the History, Manners and Customs of the Indian Natives who once Inhabited Pennsylvania and the Neighboring States, Phila., r8x9.

2 The Canadian Nanticoke are still conscious of their reputation among the Iroquois for having a dark complexion. In addition, at the Grand River reserve they are humorously accused of having large feet. 


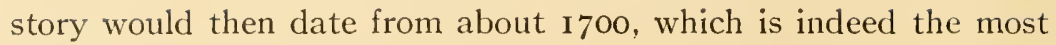
likely period for it.

Another question in this connection is, How far might northern African influence have survived in industry and folklore? Family names betray only English origins, with one exception: that of "Bumbery" may indeed possibly be a corruption of Barbary." African influence, however, is shown most conclusively by the fact that a list of Nanticoke numerals (I to Io) recorded by Pyrlæus, a missionary to the Mohawk in I780, proved, through the investigations of Dr Brinton, ${ }^{2}$ to be Mandingo or a closely related West African language.

Although the Moors or Nanticoke were included with the "colored people" during slave days, none of them were ever held as slaves. They claimed the right to carry firearms, and in the local court forty or fifty years ago one of their number won a case, arising from the ownership of firearms, by proving himself to be a "native Indian without a drop of slave blood in his veins." In recent years, as the outcome of an effort led by one of the band, Mr W. R. Clark, the Nanticoke have secured legal recognition at the Delaware State capital as Indians and exemption from regulations applying to negroes.

Reverting again for a moment to the question of English ancestry, we find that the band speaks a dialect of English distinct from that spoken in other parts of Delaware and Maryland. In another part of this paper I have noted some phonetic peculiarities and words and expressions peculiar to the community, which with tracing the family names ${ }^{3}$ may some time afford a clue respecting its

1 The same family name (Bounberri), strange to say, is found among the Canadian Cayuga. The Cayuga are said to have adopted the Nanticoke in 1753 . It is just as likely, however, that the name is from Vambery.

${ }^{2}$ Cf. American Antiquarian, I887, vol. 1x, p. $35^{2}$.

${ }^{3}$ The names of families of the Nanticoke community in Sussex county are here given. They comprise a majority of the inhabitants of the district known as Indian River Hundred, from near Millsboro eastward along the northern shore of Indian river to near Lewes, and northward nearly to Georgetown. These names are: Rogers, Jackson, Wright, Thompson (part negro), Harmon, Street, Norwood, Coursey, Morris, Clark, Johnson, Drain, Moseley, Sockume, Burton, Davis, Bumberry, Layton, Miller, Thomas, Cormeans, Hanzier. They have the peculiarity of calling the children by the parents' names, as Levin's Isaac, Noah's Jim, Eliza Ann's Jane, etc. 

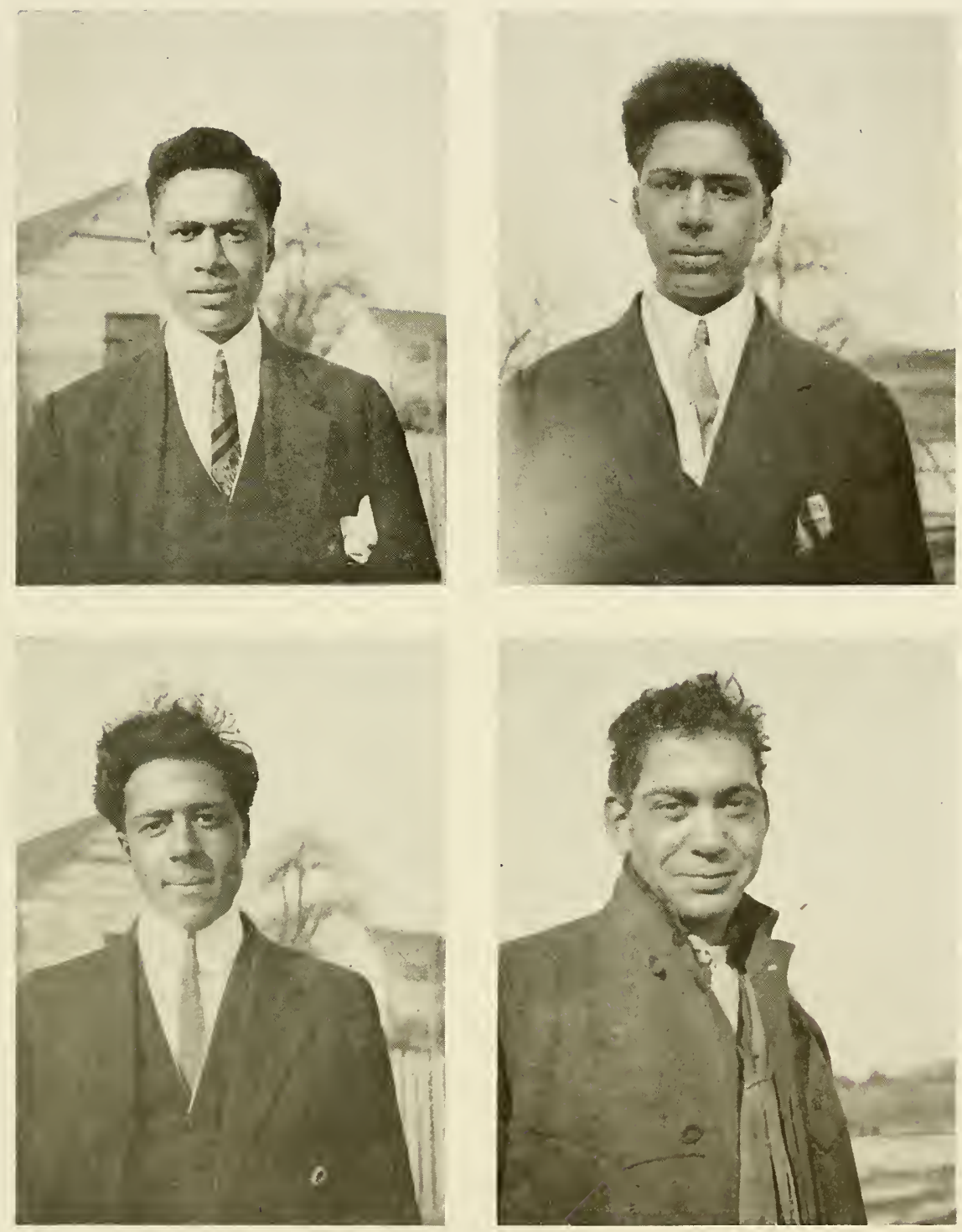

NANTICOKE TYPES

(THE UPPER TWO AND THE LOWER LEFT-HAND BOYS ARE BROTHERS) 

derivation. A comparison of these with the family names and dialectic peculiarities of the so-called Croatan settlement in North Carolina is interesting, because the latter are in a somewhat similar position, being reputed descendants (with little basis of fact, however) of colonists from southern England, conducted to America by Sir Walter Raleigh ( $5^{87}$ ), who became merged with the natives of the coast. In comparing the vernacular and family names of both communities we find no correspondences. ${ }^{1}$

Finally, in discussing the origin of the Nanticoke community we should not overlook the fact that one at least of the older men, Lemuel Sockume, claims that their Indian ancestors were Cherokee. I do not know how to coördinate this assertion with the known facts of the case, unless it be that Cherokee at some time joined the Nanticoke band and left descendants there. Some of them claim also a trace of French blood.2

Unfortunately nothing of the Nanticoke language remains, not even a trace.

Part of my task amorig these people was the gathering of ethnological specimens. Accordingly a collection of about one hundred objects of industry were obtained from the older families, illustrating life in past generations. This collection is now in possession of the Museum of the American Indian in New York, in whose interest the latter part of the investigation was conducted. The illustrations of objects in this paper are from drawings of the originals in that Museum.

Considering the value that the following fragments of material life and folklore may have, either from the point of view of survivals of Indian culture or as possible secondary independent folk developments, I shall include a few introductory historical references.

${ }^{1}$ An interesting study of the Croatans of North Carolina has been made by $\mathrm{H}$. McMillan, Sir Walter Raleigh's Lost Colony, Raleigh, N. C., I907, pp. 35-36. Cf. also N. E. Fitch, "The First Founders in America, with Facts to Prove that Sir Walter Raleigh's Lost Colony was not Lost," N. Y. Society of the Order of the Founders and Patriots of America, I9I3, p. 39. Incidentally these authors both refer to the use of the wooden crossbow, an article borrowed from the early explorers and found among the Algonkin tribes as far as the Montagnais of Labrador.

2 The family name of Hanzier (pronounced Hä'nzer) is said to be of French origin. Mrs Bumbery says that her grandmother, who was a Hanzier, could speak French. 


\section{HISTORY}

The Nanticoke Indians of southern Delaware were first encountered in I 608 by Captain John Smith. ${ }^{1}$ They then occupied the peninsula between the Atlantic ocean and Chesapeake bay. Smith spoke of them in the following terms:

"We set saile for the maine; and fel with a faire river on the East called Kuskarawaocke. By it inhabit the people of Soraphanigh, Nause, Arsek, and Nautaquake, that much extolled a great nation called Massawomekes . . ." 2

"On the east side of the Bay, is the river Tockwhogh, and upon it a people that can make Ioo men, seated some seaven myles within the river: where they have a Fort very well pallisadoed and mantelled with barkes of trees. Next them is Ozinies with 60 men. More to the South of that East side of the Bay, the river Rapahanock, neere unto which is the river Kuskarawaock. Upon which is seated a people with 200 men. After that, is the river Tants Wighcocomoco, and on it a people with roo men. The people of these rivers are of little stature, of another language from the rest [referring to the Powhatans], and very rude. But they are on the river Acohanock with 40 men, and they of Accomack 80 men doth equalize any of the Territories of Powhatan, and speake his language; who over all those doth rule as King." 3

To bring these related matters together as much as possible, John Smith's map is here reproduced (pl. I).

Subsequently the Nanticoke are heard of through their connection with the related tribes along the Susquehanna and on the western shore of Chesapeake bay. References bearing exclusively on the Indians who remained on the eastern shore are scanty and convey little information concerning their mode of life. From I64I to I 648 they were at war with the colonists. By I748 most of the Nanticoke and Conoy of Maryland had moved up the Susquehanna to the Iroquois, with whom they gradually became affiliated. By I 799 the Nanticoke had sold all their land in Mary-

${ }^{1}$ Captain John Smith's Works (1608-163I). English Scholar's Library, edited by Edward Arber, Birmingham, England, I884.

2 Ibid., p. I I I.

3 Ibid., p. 35 I. (1607-09.) 

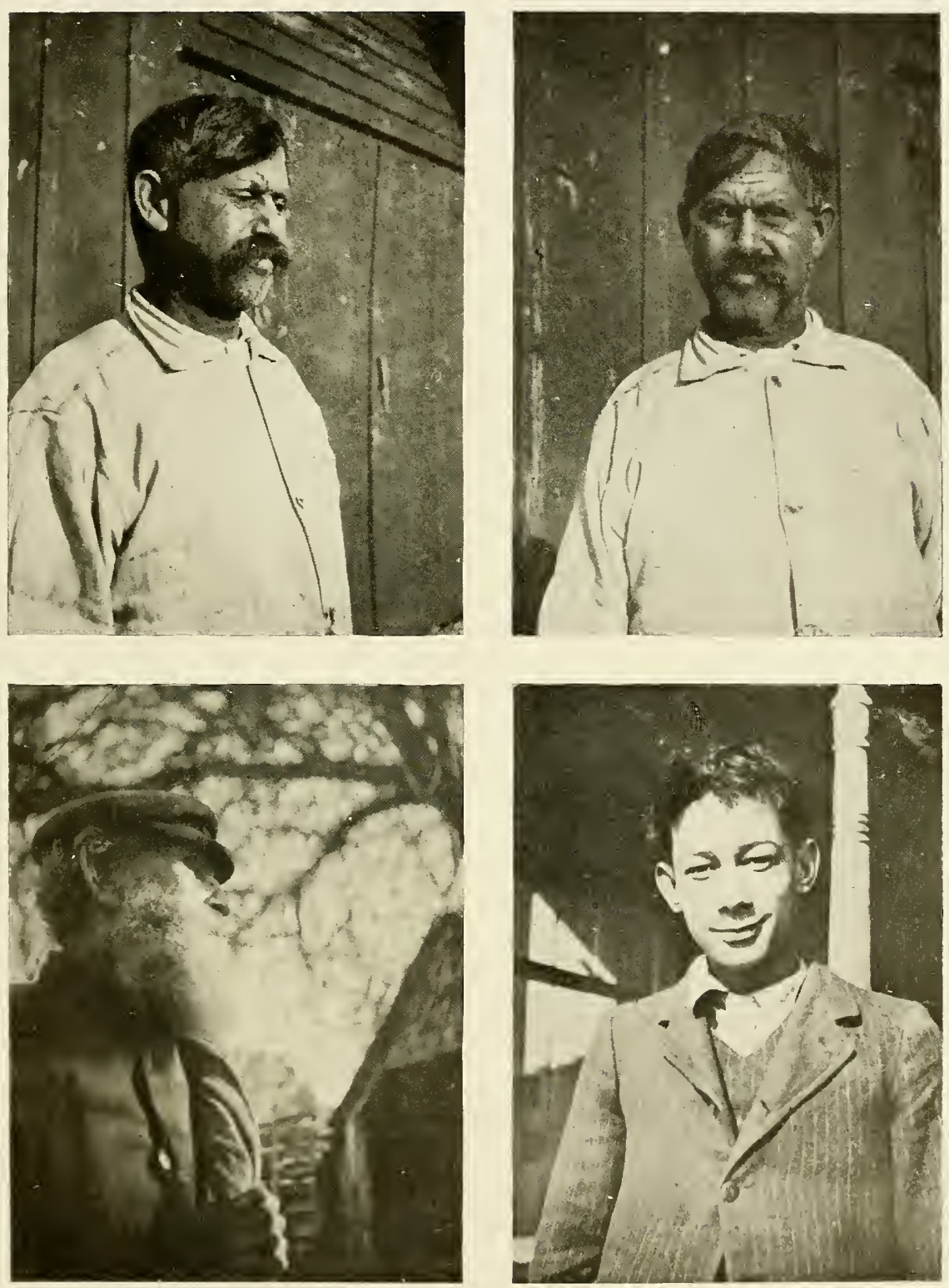

NANTICOKE TYPES

(THE UPPER TWO ARE FULL-FACE AND PROFILE PORTRAITS OF THE SAME MAN) 

land. Since it is not the intention in this paper to deal with the bands of the western shore, ${ }^{1}$ nor with the Nanticoke in general after their adoption by the Iroquois in 1753 , we shall have to leave the historical documents and depend on local traditions of the people of the region. ${ }^{2}$

The last authentic reference, however, to the Nanticoke in their old haunts, and the one to which we are indebted for knowledge of the language, is that by William Vans Murray, who in 1792 sent a few ethnological notes and a vocabulary collected at the Nanticoke village of Locust Neck Town, Goose creek, Choctank river, Dorchester county, Maryland, at the instance of Thomas Jefferson. ${ }^{3}$ In a letter accompanying the vocabulary he wrote that the tribe had dwindled to nine persons. They lived in "four genuine old wigwams thatched over with the bark of the cedar." They were governed by a "queen," Mrs Mulberry. The rest had removed "to the Six Nations ... . They went to the Senecas often." A note to the vocabulary adds that Wyniaco, their last

1 The inhabitants of the Maryland shore probably formed a separate band of the Nanticoke, differing in some details from those of the eastern shore. An alliance existed between them as late as 1660 , according to Colonial records. Since the Canadian Nanticoke came mostly from Maryland proper, they should be classed as a separate band, or at least as one comprising several dialects. One of these, if not the predominating one, was the Conoy or Kanawha, judging by a comparison of the older Nanticoke material with a vocabulary from the present Canadian division of the tribe, and also from a tribal synonym by which the latter are known as Ganáwagohono (Cayuga), "swamp people" (Kanawha).

${ }^{2}$ During the winter of I9I4 I visited the Nanticoke incorporated with the Six Nations of Iroquois at Ohsweken, Ontario, where several hundred descendants still retain their identity as a body in the League. The ethnological results of this trip, with a Nanticoke vocabulary, are being prepared for a special paper on the emigrant portion of the tribe. The Nanticoke in Ontario were greatly interested in learning through me of their kinsmen in Delaware, of whom they had heard occasionally. Some family names are common to both bands. The last actual contact between them, according to the memory of the Canadian Nanticoke, was in the middle of the last century, when several families from the South, presumably from Delaware, were refused admission into the Canadian band on account of their dark complexion. The name of one of these families was Burton, according to memory, which incidentally corresponds with a common family name of those still in Delaware. In 1857 the Canadian Nanticoke sent a chief (Cornelius Anderson) and two delegates to Maryland to look up survivors, but they found none there.

${ }^{3}$ D. G. Brinton, "A Vocabulary of the Nanticoke Dialect," Proceedings of the American Philosophical Society, vol. xxxi, I893, pp. 325-333. 
"king," had died about 75 or 80 years before and that his body was kept preserved in a mortuary house. The custom of preserving the bones of the dead was early recorded of the Nanticoke. The names of two Nanticoke villages are given in this notice, "Ama namo quun, the name of the Indian town of Locust Neck. Mattappenen, the name of the Nanticoke Indian town." Beverley ${ }^{1}$ in I 722 mentioned the principal village of the tribe as Nanduge, with Ioo inhabitants, ruled by an "empress." 2

Regarding tribal identity and history, a few interesting fragments of tradition survive among the people. The Nanticoke are said to have inhabited the coast and inlets no farther north than Indian river. Inland, however, they ranged westward across Chesapeake bay.. Evidently the present remaining descendants of the tribe at Indian river were the nucleus of those who stayed in Delaware after the general break-up of national life, before $\mathrm{I} 748$. The country north of the Indian River district, according to surviving tradition, was neutral ground between the Nanticoke and the Delawares proper, who, the former assert, were not always on the best of terms with the Nanticoke of Indian river. This would make the ancestry of the Cheswold branch of the Indian remnant in Delaware not fundamentally Nanticoke, but Delaware. Of course it should be remembered that intermarriage and removals have been frequent between the two bands, so that now, to all intents, they are practically the same, differing only in the degree of white and negro intermixture. According to Mr Clark's testimony, early in the last century many families emigrated from Indian river to the west, for the purpose of joining some tribes nearer, or across, the Alleghanies. This probably refers to the general Indian emigration from the coast to the adjacent slope, during the middle of the eighteenth century, with the Delawares and others.

Subsequent to this movement representatives from the departed band occasionally returned to Indian river to visit their friends and relatives; particularly to visit old Mrs Lydia Clark, the grand-

${ }^{1}$ History of Virginia, 2d ed., London, I722. Possibly namóq'wan, "fish catching," and, nadápenan, "landing place."

${ }^{2}$ Among the Canadian Nanticoke the term "emperor," denoting head-chief, is still in use. 

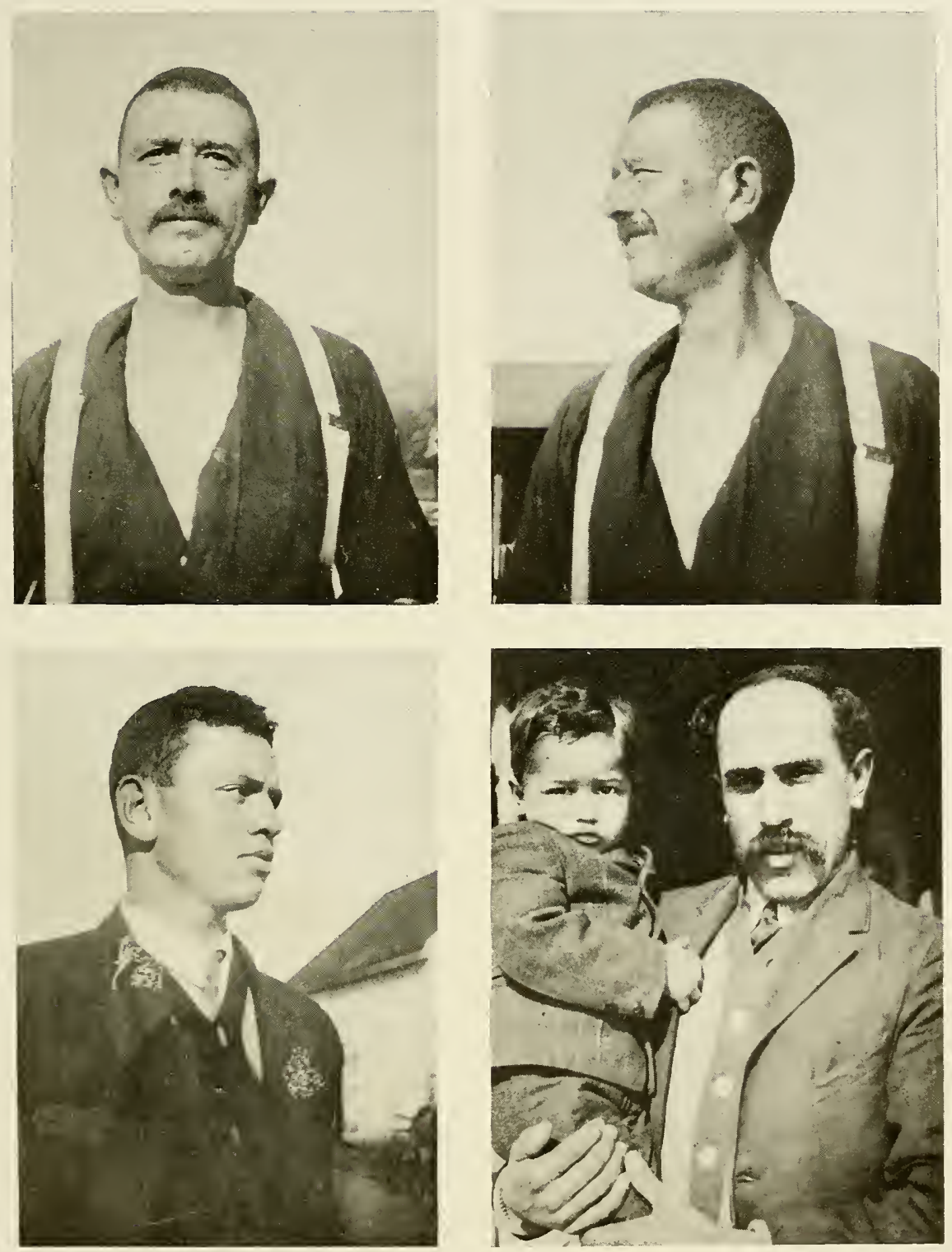

NANTICOKE TYPES

(THE UPPER TWO ARE PORTRAITS OF THE SAME MAN. THE LOWER LEFT-HAND PORTRAIT IS THAT OF HIS SON) 

mother of our chief informant, Mr W. R. Clark, who was then the only person who spoke the Nanticoke language and who wore in part the native costume. After her death, probably between I 840 and $185^{\circ}$, these Indians did not come again, and the Indian River remnant was left without communication with its kin. Again, however, a number of families emigrated from Indian river. ${ }^{1}$

These seem to have been the last important events in the history of the community, excepting the occasion of a church quarrel over the admission of negroes to church and school privileges, which resulted in the division of the band into two factions. The original exclusive party is still known as the Indian River or Warwick Indian community, the seceders, who admit social rights to outsiders, calling themselves the Harmonia people. These later distinctions, however, are of minor importance.

\section{Physical Character of the Region}

A few words concerning the physical character of the Nanticoke country will not be out of place. The surface is extremely flat; the land a sandy bottom without stones, a fact thai becomes important when it is remembered that all the stones (steatite, jasper, quartz, chert, etc.) used in making implements by the original natives had to be imported from the western shore of Chesapeake bay or overland from north of Dover. The geographical features of the section are characteristic of the Atlantic coastal plain to which it belongs, not differing noticeably from the Carolina coast.

Tall, columnar, yellow pines and spruce pines form the forest growth that still covers much of the Indian River country, but this is interspersed with oak, sassafras, holly, maple, cedar, dogwood, and smaller trees. In spring the white dogwood blossoms show brightly through the dark pines, but give place to the dryer green-

${ }^{1}$ About 1855 some fifty members of the Sockume, Miller, and Norwood families moved to San Francisco, California, where their descendants still live. In I865 members of the Johnson and Harmon families moved to Blackwood Town, New Jersey. For many years there were Nanticoke colonies in Gloucester, New Jersey, and Philadelphia. In I87o about fourteen Clarks, Millers, and Johnsons moved from Gloucester to near Detroit, Michigan, and in 1887 six of the Thomas family moved from Philadelphia to Nova Scotia. 
ness of midsummer. The leaves fall late in October or early in November. More or less continued cold weather comes by December and lasts through February, during which snow is common, though not remaining on the ground for more than a day or two at a time. Frost does not penetrate deeper than a few inches, and does not remain more than a few weeks. Seasons during which Indian river freezes over for more than a few days at a time are rare. The summers, as might be expected in this locality, are hot and humid. Mosquitoes are very troublesome and cause considerable ague, as one might suspect from the number of herb cures for this malady to be listed later.

\section{Agriculture AND Food}

In the present-day life of the community no industry shows more surviving native characteristics than that pertaining to corn. Of the four varieties of native corn raised, two of them, the white and the yellow, are early; the others, namely, "sheepshank," or flint, and popcorn, are late. Incidentally the same varieties were recorded among the Virginia Indians by Robert Beverley in $1722 .^{1}$ The "sheepshank" is planted late nowadays, mostly in rather poor or waste ground. After the sandy fields have been plowed, sowing begins, about May io to I5. Some superstitions are observed in the planting: for instance, corn should not be sown while the wind is from the east; it should be sown before noon, and when the "moon is filling," that is, when it is on the increase. Also in regard to agriculture, we learn that potatoes and wheat must be planted in the light of the moon, and tomatoes should not be planted while the wind is easterly. Furthermore, watermelon-seed should be sown before sunrise on May 12.

Returning to the cultivation of corn, we encounter an interesting implement known locally as a "suckerin' cane," used during the early season. This is a crooked stick of oak with a natural bend forming a grip, the whole averaging 22 to 26 inches in length (fig. I). This implement is employed by the men, who go through

1 See Willoughby, "The Virginia Indians in the Seventeenth Century," American Anthropologist, N. S., I907, vol. 9, no. I, quoting Beverley, History of Virginia, 2d ed., I 722, p. 18 . 

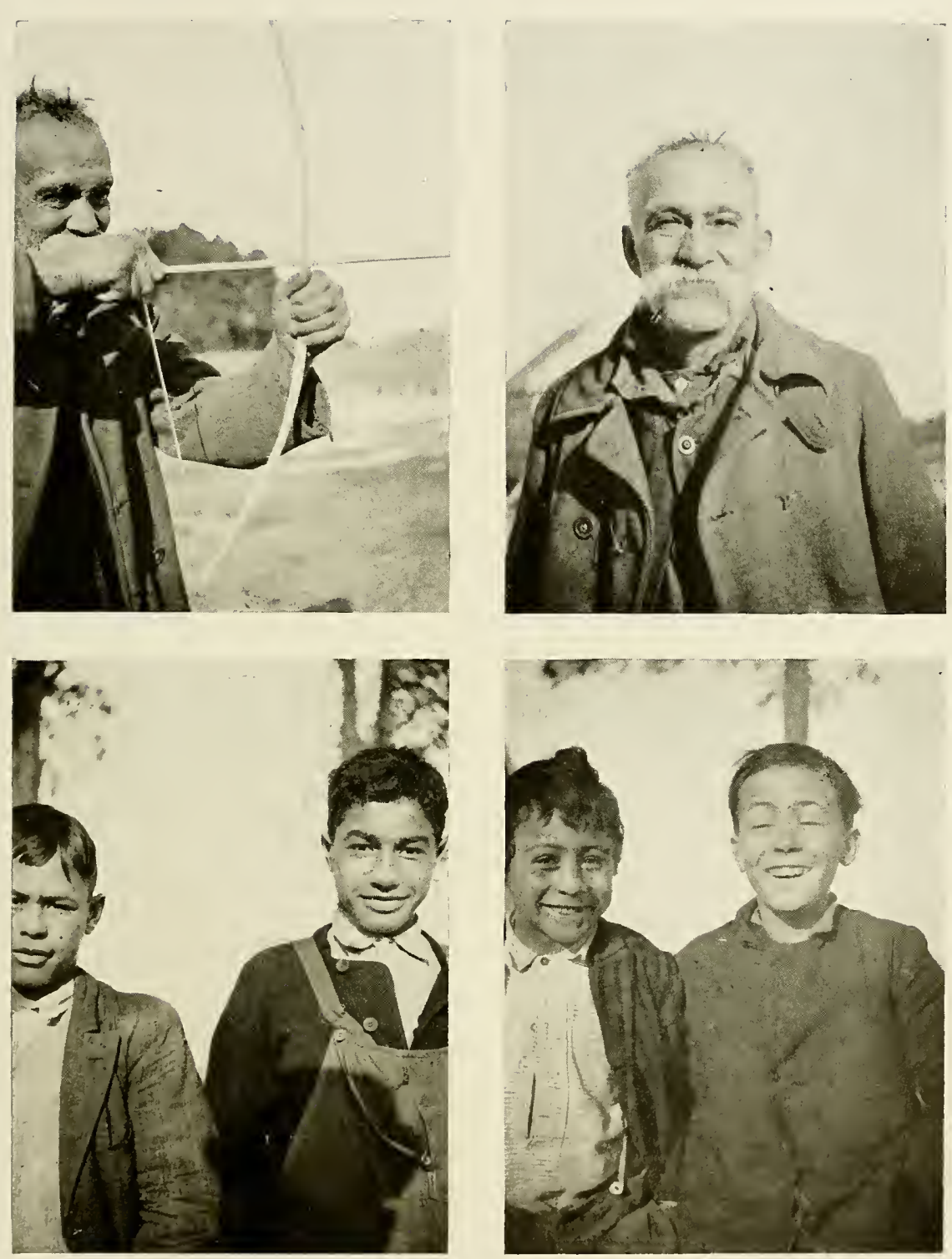

NANTICOKE TYPES 

the fields pulling out the surplus sprouts in the corn-hills. They rest their weight upon it like a cane, when they bend over and pull out a sprout. The sharp end is used also to poke holes in the hills where other grains of corn are needed to be planted. This is manifestly the old planting-stick surviving in serious use.
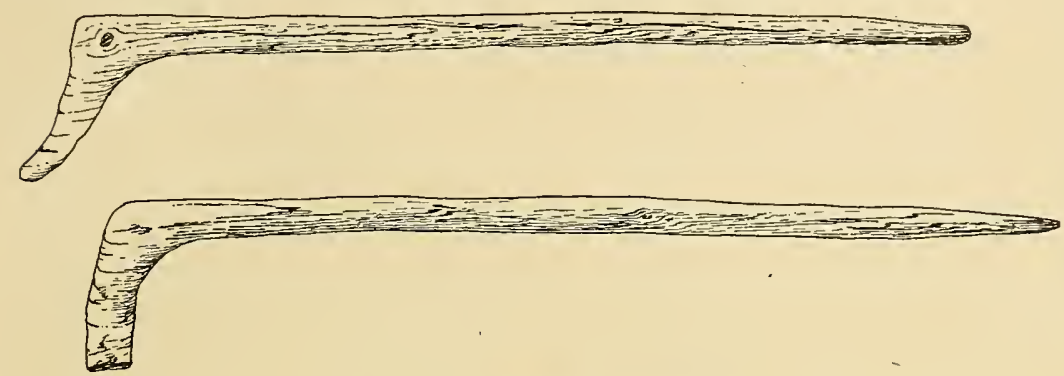

FIG. I.-“"Suckering" canes.

The next operation deserving notice is the "topping" and "stripping" which take place when the kernels have formed sufficiently and the milk will not run when, as a test, the kernel is cut with the finger-nail. The topping consists in cutting off the stalk above the uppermost ear, while stripping refers to cutting off all

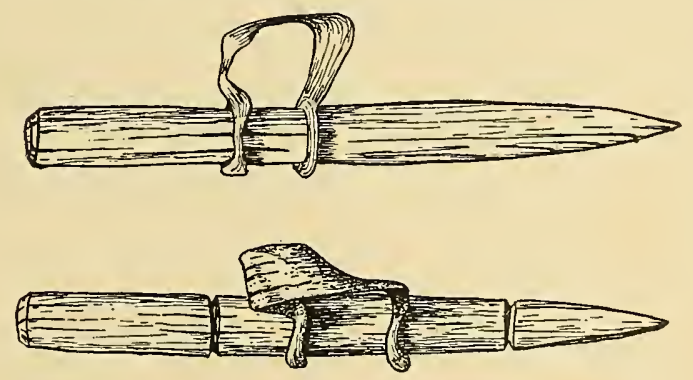

FIG. 2.-Corn-husking pegs.

the leaves. This practice is an old one among the farmers throughout southern Delaware, and locally is attributed to the Indians. The tops and leaves are used as fodder for stock in this region, where little or no grass for hay grows. When the corn is to be harvested, the men enter the fields and husk the ears, throwing them into heaps, which are then gathered in large baskets by 
children and helpers. A husking-peg of hard oak, five to six inches long (fig. 2), with a leather finger-loop, is used. This article is practically the same as that found among the Iroquois, Pamunkey, Mohegan, and other Southern tribal remnants. Finally the corn crop is stored in the large characteristic corn-cribs, made of logs (pl. $\mathrm{xv}$ ), which may possibly preserve some aboriginal constructional features, since the entire corn industry is derived from the Indians, and many of the implements used with it have survived in one form or another.

In the first stage of the preparation of the corn for use, an interesting device for shelling the corn from the cob is found. This consists of a large, hollow log from a gum tree, 29 in. high and 27 in. wide, with walls $\mathrm{I} \frac{1}{2}$ in. thick. Its widest part is uppermost, with a row of eleven wooden bars, $I \frac{1}{2}$ in. thick, reaching across the cavity like a grating, a foot from the ground or lower elge. The husked ears of corn are put in the upper cavity and beaten with a pestle made by fastening an iron wedge into a notched staff. The loosened kernels fall through the grating into the lower compartment, from which they are shoveled out through the aperture. One of these old corn-shellers is shown in operation in plate xvi. This apparatus is known to have been used by the Nanticoke from the time of their earliest remembrance. One wonders if it is a strictly aboriginal invention, since nothing like it has been reported elsewhere on the continent. The natives, of course, in preparing small quantities, sometimes shell the corn by grating it with another cob.

Next the usual corn mortar and pestle are used to pound the corn into grits or flour. The mortars of the Nanticoke are evidently of native origin. Nearly every family possesses one. They are all of one type (pl. xxi), tapering toward the base. The hominy mortar is made of gum-wood. The outer surface is shaped with an axe; the cavity is made by drilling a deep hole into the top of the $\log$ and putting fire therein, which is replenished until it has burned near enough to the edge. The pestle is the same as the one above described. The kernels of corn are pounded to grits in the mortar, the chaff and hulls being separated by scooping up the 

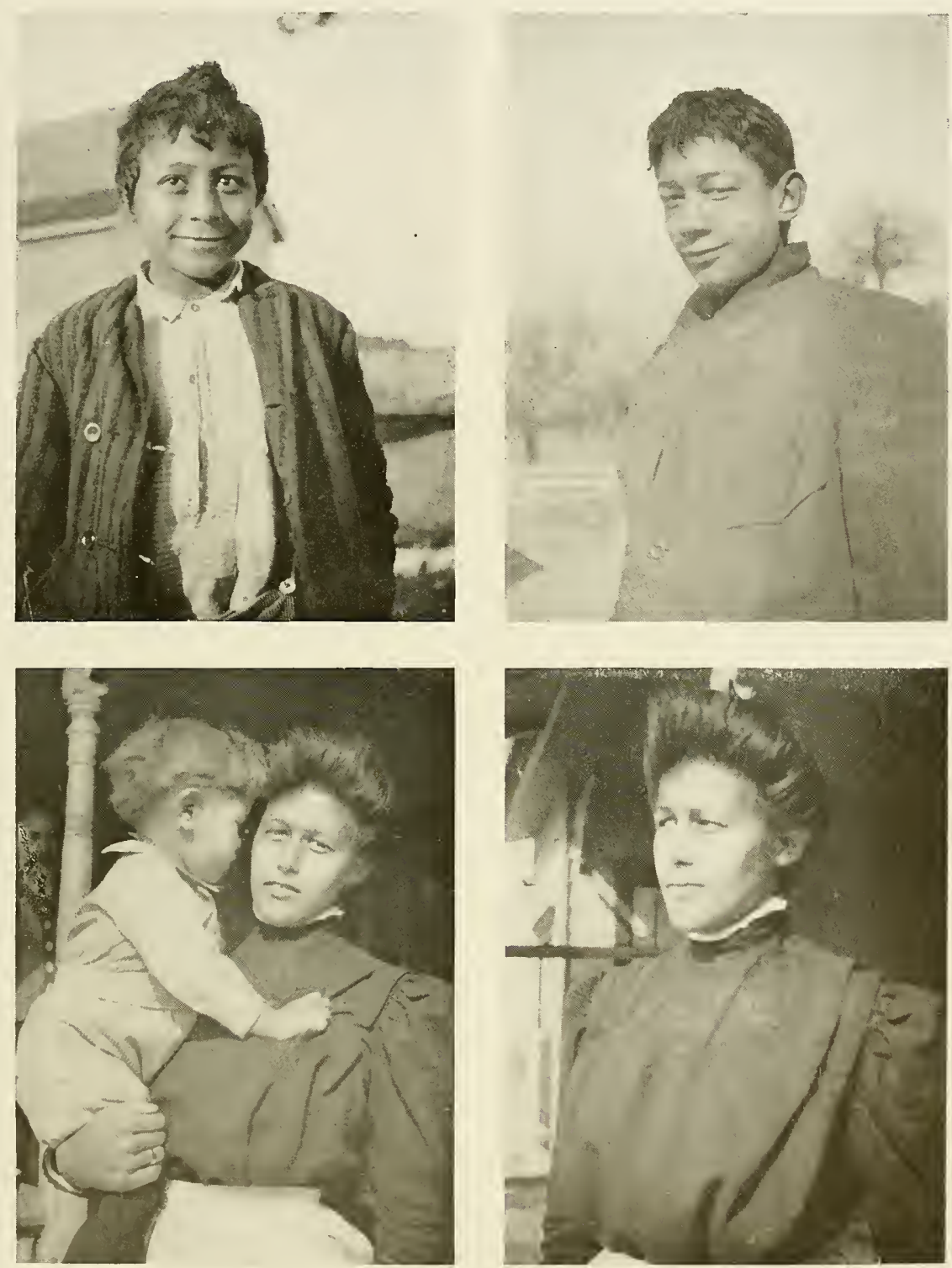

NANTICOKE TYPES

(tHe LOWER tWo aRe FULL-FACE AND PROFILE PORTRAITS OF THE SAME WOMAN) 

grits in a basket and pouring them again into the mortar from above, or from one basket to another, allowing the wind to blow the waste away. Sieves seem to have been unknown. By repeating the pounding and pouring operation, the corn is ground and cleaned until fit to be used as hominy or for bread. Smaller mortars of the same shape, though some straight-sided ones are found, are employed for pounding coffee and medicinal plants (pl. XxI). In shape these mortars are unlike the plainer ones of the Southern tribes, and they are not found in use among the whites. Some have cavities in the bottom for cracking hickory-nuts.

Following are the dimensions (in inches) of Nanticoke wooden mortars in the Museum of the American Indian:

\begin{tabular}{|c|c|c|c|c|c|c|}
\hline Material & Height & $\begin{array}{c}\text { WIDTH AT } \\
\text { TOP }\end{array}$ & $\begin{array}{c}\text { NaRRowEST } \\
\text { PART }\end{array}$ & BASE & $\begin{array}{c}\text { Defth of } \\
\text { Cavity }\end{array}$ & $\begin{array}{l}\text { Thickness } \\
\text { OF WALL } \\
\text { AT RiMI }\end{array}$ \\
\hline Gum........... & 29 & I2 & 7 & I I $\frac{1}{2}$ & I 5 & $I \frac{1}{4}$ \\
\hline Gum........... & 32 & I6 & 8 & I $5 \frac{1}{2}$ & 12 & $\mathbf{I} \frac{1}{2}$ \\
\hline Gum........... & I 4 & $7 \frac{3}{4}$ & 4 & 7 & $8 \frac{1}{2}$ & $\frac{1}{2}$ \\
\hline Locust........... & I 7 & 7 & $4 \frac{3}{4}$ & $7 \frac{3}{4}$ & 4 & I \\
\hline Gum........ & I 2 & 6 & 2 & 6 & 6 & $\frac{3}{1}$ \\
\hline Gum........... & 33 & I3 & $4 \frac{1}{2}$ & I3 & I2 & $I^{2}$ \\
\hline Gum........... & 34 & I2 & $6 \frac{1}{2}$ & I I & I 8 & $I_{2}^{\frac{1}{2}}$ \\
\hline
\end{tabular}

The stirring paddles used by the Nanticoke when making mush or pone are of two general sizes. The longer ones (fig. 3) are 28

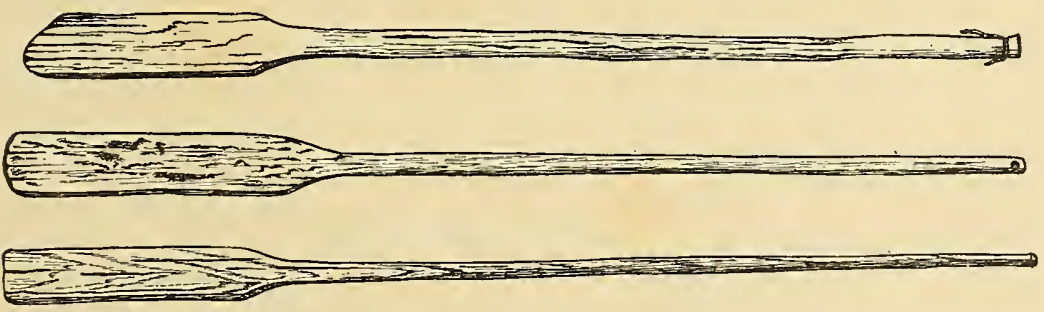

FIG. 3.-Large stirring paddles.

to $30 \mathrm{in.}$ long, with blades $I \frac{1}{2}$ in. wide, and are made of white oak or of yellow pine. The smaller paddles are from I7 to I9 in. long (fig. 4) and are much used nowadays in making butter. Although the stirring paddles are extremely plain, the nearest people whose 
paddles they resemble, excepting the remnant of the Powhatan Indians of Virginia, are the Cherokee of North Carolina, whose paddles are identical.

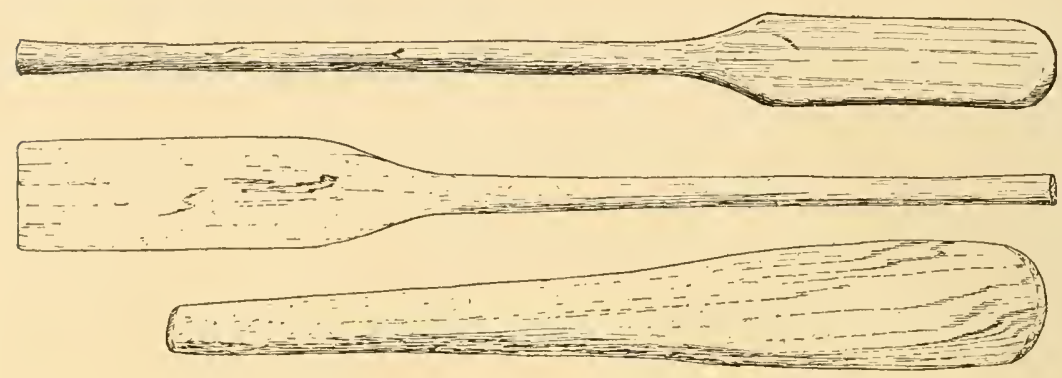

FIG. 4.-Small stirring paddles.

A large, cumbersome, spoon-like ladle, evidently of cypress (fig. 5), was also used for stirring food in a cauldron. An individual spoon obtained from a Nanticoke near the ocean at Lewes, is made of red oak, with a bowl 3 in. wide and a handle Io in. long. It was used for eating corn and beans.

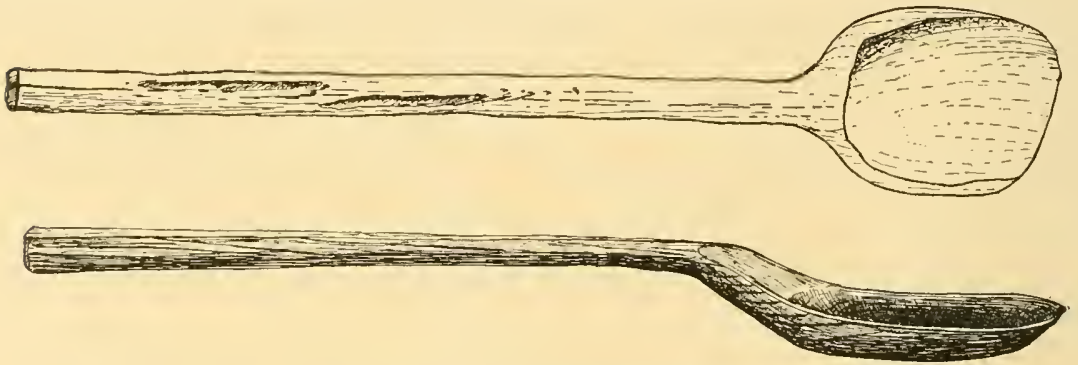

FIG. 5.-Wooden ladles for stirring.

Some old-fashioned foods of Indian origin have survived. Among these is found the "ash cake"- a disc of corn dough, six inches or so in width, wrapped in large, damp leaves and placed in the ashes of a dying fire. Another food is "johnny-cake" (journey cake), made of corn flour and water mixed to dough and spread upon an oak board which is then tilted obliquely on its side before an open fire until the cake is browned. A very old "johnny-cake" board, $18 \mathrm{in}$. long, 4 in. wide, and $\frac{3}{4}$ in. thick, is shown in figure 6 . 

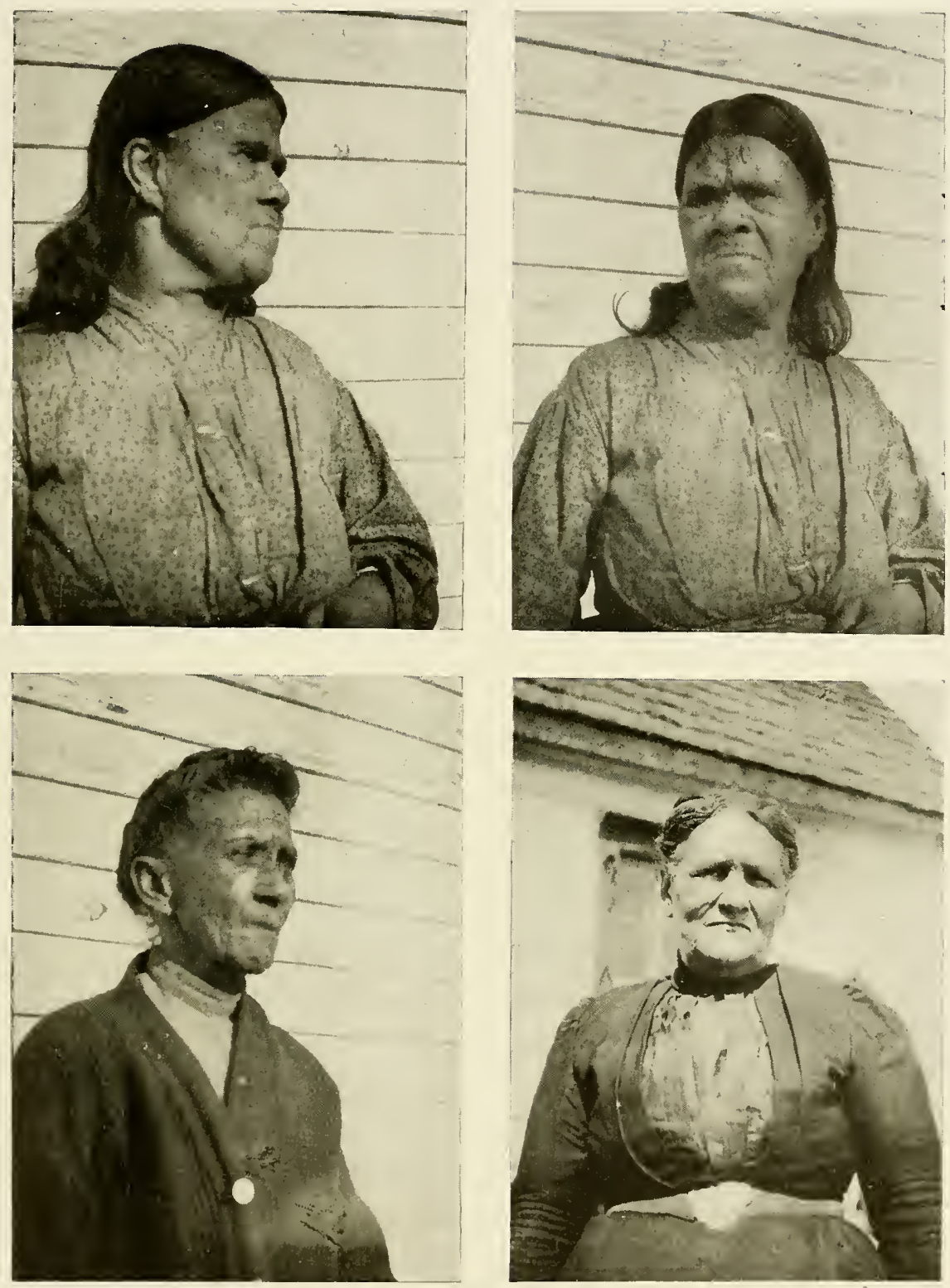

NANTICOKE TYPES

(THE UPFER TWJ ARE PORTRAITS OF THE SAME WOMAN) 

Johnny-cake was the staple of these Indians in former times, and with roasted or boiled meat and fish constituted the chief diet.

"Pone," 1 the next important food, consists of corn-meal salted to taste, mixed with water, placed in a vessel, and cooked in an oven over night. This makes a nourishing but rather heavy loaf, which is very popular when eaten with cane molasses.

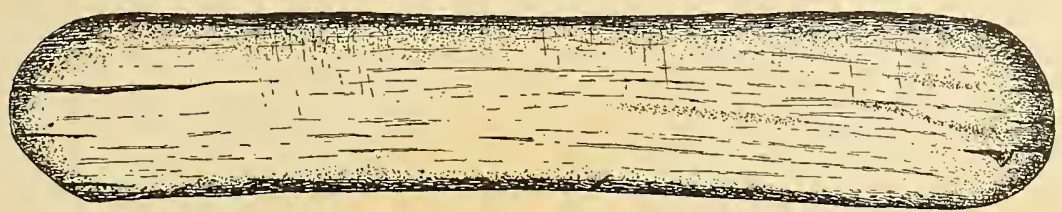

FIG. 6.-Johnny-cake board.

According to another native recipe meat is mixed with hominy and boiled in the form of a stew. The meat of all kinds of wild game is stewed or fried. Muskrats are made into a stew, as are also raccoons and opossums.

\section{Fishing AND Hunting}

Indian river abounds in fine, edible fish, many of which come in as they enter Delaware bay to ascend to their spawning waters. Among the chief fish are shad, herring, drum, perch, and latterly carp. Fishing, indeed, forms one of the leading activities of the Nanticoke, and is followed as a business by some of them. Among the devices for taking fish, some are probably of aboriginal origin while others have been modified by modern usage.

The Nanticoke use the eel-pot, so characteristic of all the tribes south of the St Lawrence along the Atlantic coast, making it of pine and of oak splints from half an inch to an inch wide in the simple twill weave, with an indented bottom to serve as an entrance, the inward projecting standards preventing eels or other fish, having once entered, from passing out again. The eel-pots are between 18 and 26 in. in length, about 9 in. wide at the bottom, and 5 in. at the top. Several specimens of pine and of oak splints are shown in plate XIX. The opening at the top is here

${ }^{1}$ This term is probably derived from old Nanticoke $a^{\prime} p a^{\circ} n$, "bread" (Canadian dialect). 
generally closed with a wooden plug. The eel-pot is sunk with stones on the bottom along the shore, or is put at the mouth of a fyke, to be described later.

Fish-nets are found in nearly every family of the tribe living within a mile or so of the river. They are now made of the cord of
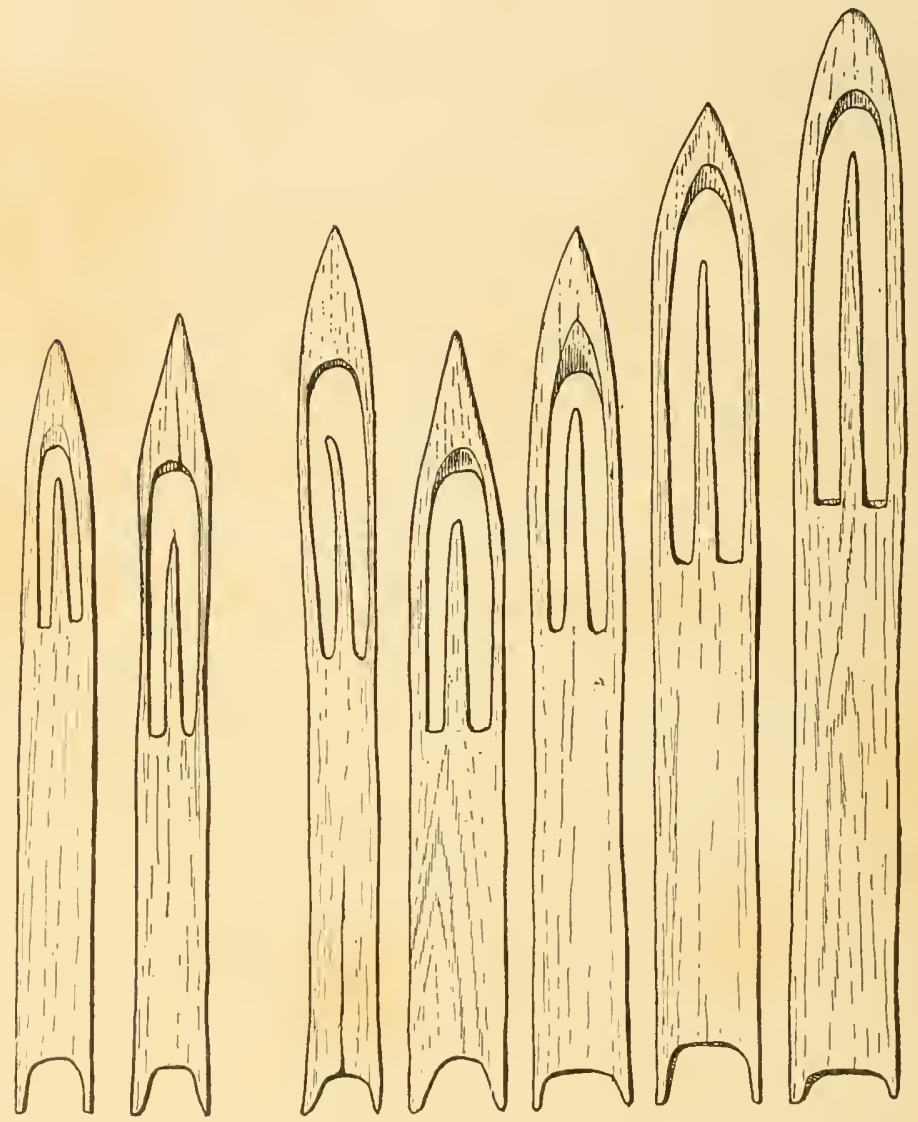

FIG. 7.-Netting-needles. The first two examples are for making herring nets, the others for making nets for sturgeon, drum, and shad.

commerce. The netting-needles and mesh-sticks are of the form shown in figure 7 . The needles range from 6 to $9 \mathrm{in}$. in length, and from $\frac{1}{2}$ to $\mathrm{I}$ in. in width. They are all of oak, with the tongue from $\frac{1}{2}$ to 2 in. long. The mesh-blocks, of oak or pine (fig. 8), 

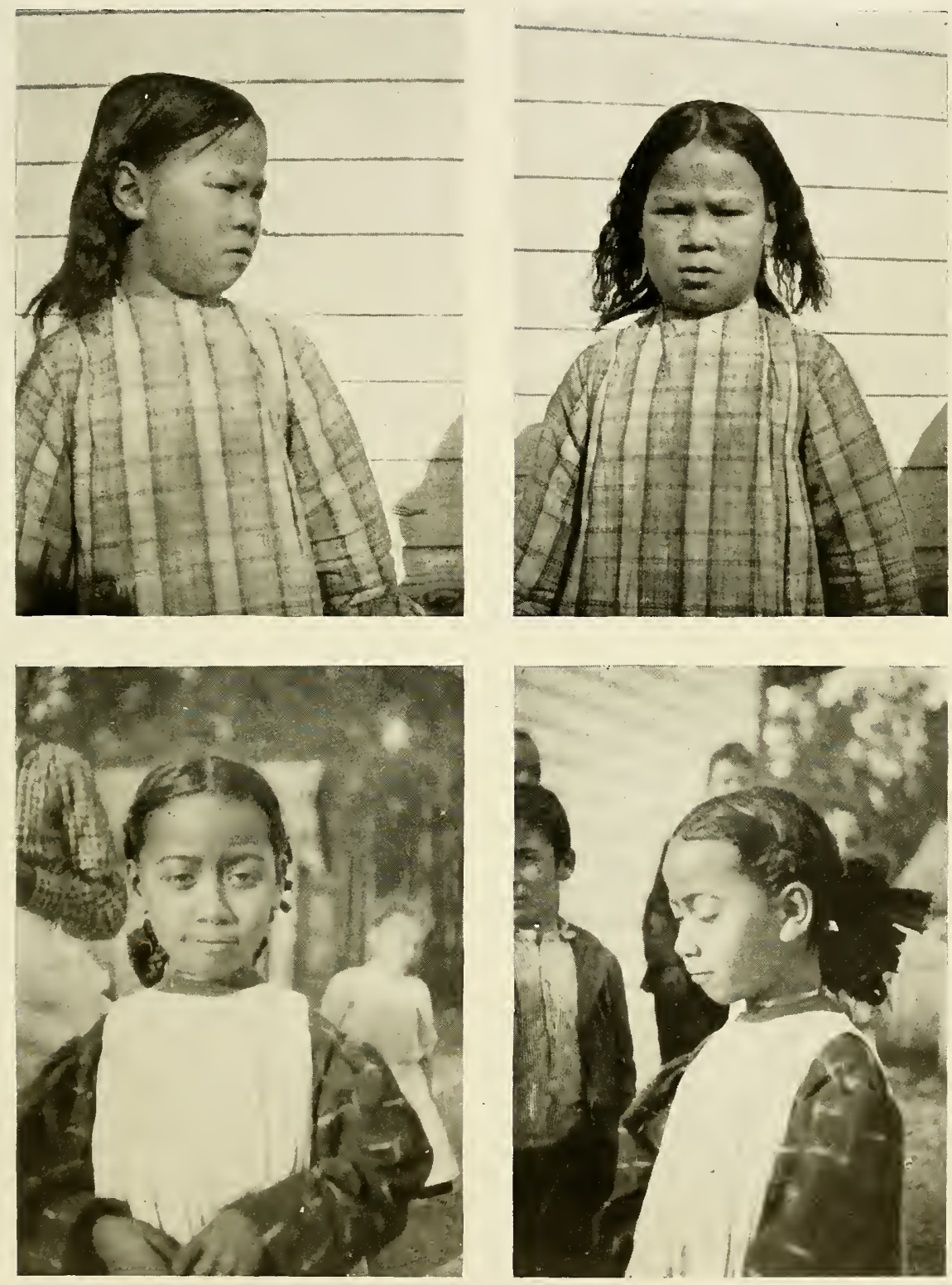

NANTICOKE TYPES

(FULL-FACES AND PROFILES. THE UPPER PORTPAITS ARE THOSE OF THE GRANDDAUGHTER OF THE WOMAN ILLUS* TFATED AT THE TOP OF PLATE VIII) 

range from $\mathbf{I}$ in. to 3 in. wide, and are generally $3 \frac{1}{2}$ to 4 inches long and $\frac{1}{2}$ inch thick. The smaller blocks are for perch and herring nets, and the larger for carp, shad, drum, and the like. The netknot, or becket, is made by taking a turn of the cord under the mesh-block and up to the top side where it is held fast by the thumb pressing the block; then a loop is thrown to the left, the needle passed through the mesh-opening just above, enclosing the cords, and the knot drawn taut.

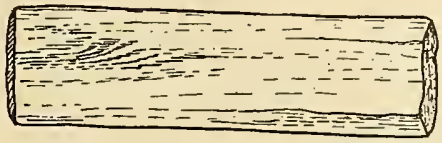

It should be noted that the netting-needles made by the Nanticoke, strange as it may seem, differ in one respect from those made by the neighboring white and black people. Among the latter, the open space and tongue of the needle are somewhat longer. This difference I have tested by observing a number of specimens both from whites and negroes in southern Delaware. Incidentally, the shape and proportions of the Nanticoke needles are practically identical with those observed among the northern Atlantic and Canadian Algonkin.
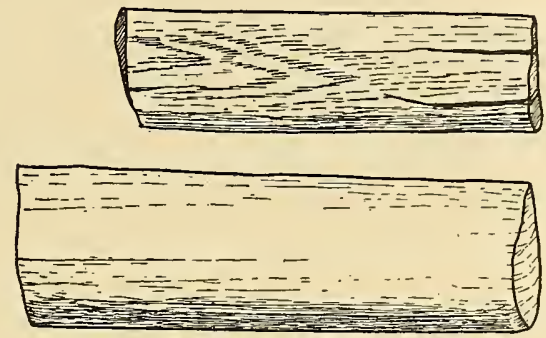

The nets are used for dragging across the channel of the river, as set or gill nets, and for fykes. A party of Nanticoke take one of the nets in a boat and row across Indian river at one of its narrower points, having left a man on shore with a long rope attached to the net. They then put the net in the water and row back to the shore whence they started. Next the man left on shore below, and those pulling farther along, gradually haul the net, like a narrowing 
bag, until it is drawn out upon a sandy beach between the two parties, where all the fish that have been drawn into it are secured. Plate Xviu shows a party engaged in seining herring by this method in April, r9r2.

For fishing in the river a fyke is commonly employed. This is made on the same plan as the basketwork eel-trap, the fish entering a funnel-shaped enclosure of network, and being prevented from getting out by the difficulty of finding their way between the strings which they passed in entering. The fyke generally has three hoops

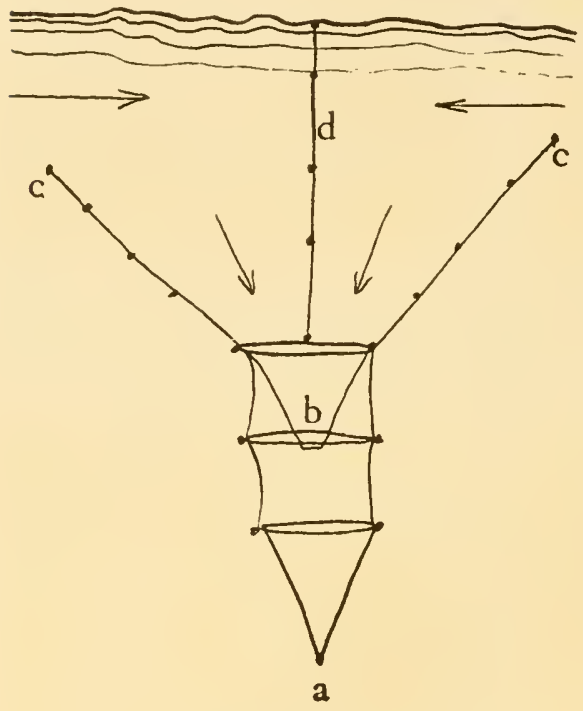

FIG. 9.-Fyke set along shore, looking downward. of wood which form the tapering enclosure, and two wings of net, branching out on each side, with a long central line of net running from the mouth of the fyke to the shore. The fykes vary in size. The smaller have hoops 29 to $32 \mathrm{in}$. in diameter, an enclosure not more than 6 or $8 \mathrm{ft}$. long, with wings about $\mathrm{I}_{5} \mathrm{ft}$. in length. The larger fykes have hoops 5 or $6 \mathrm{ft}$. in diameter, an enclosure of Io to $15 \mathrm{ft}$., with other dimensions in proportion. The floats and sinkers for the wings and runner of the fyke are the same as for the draw-nets. Figure 9 shows how the fyke is set facing the shore, with its wings and runner to guide the fish, which move along close to the shore, up or down stream, in to the enclosure.

The fyke and its runners are held in place by poles driven into the sand of the river. The arrows indicate the direction in which the fish swim; $a$ shows the rear opening of the fyke, which is closed by tying, the fishermen going out, in boats, with openbottom baskets, lifting up and opening the fyke, and transferring 

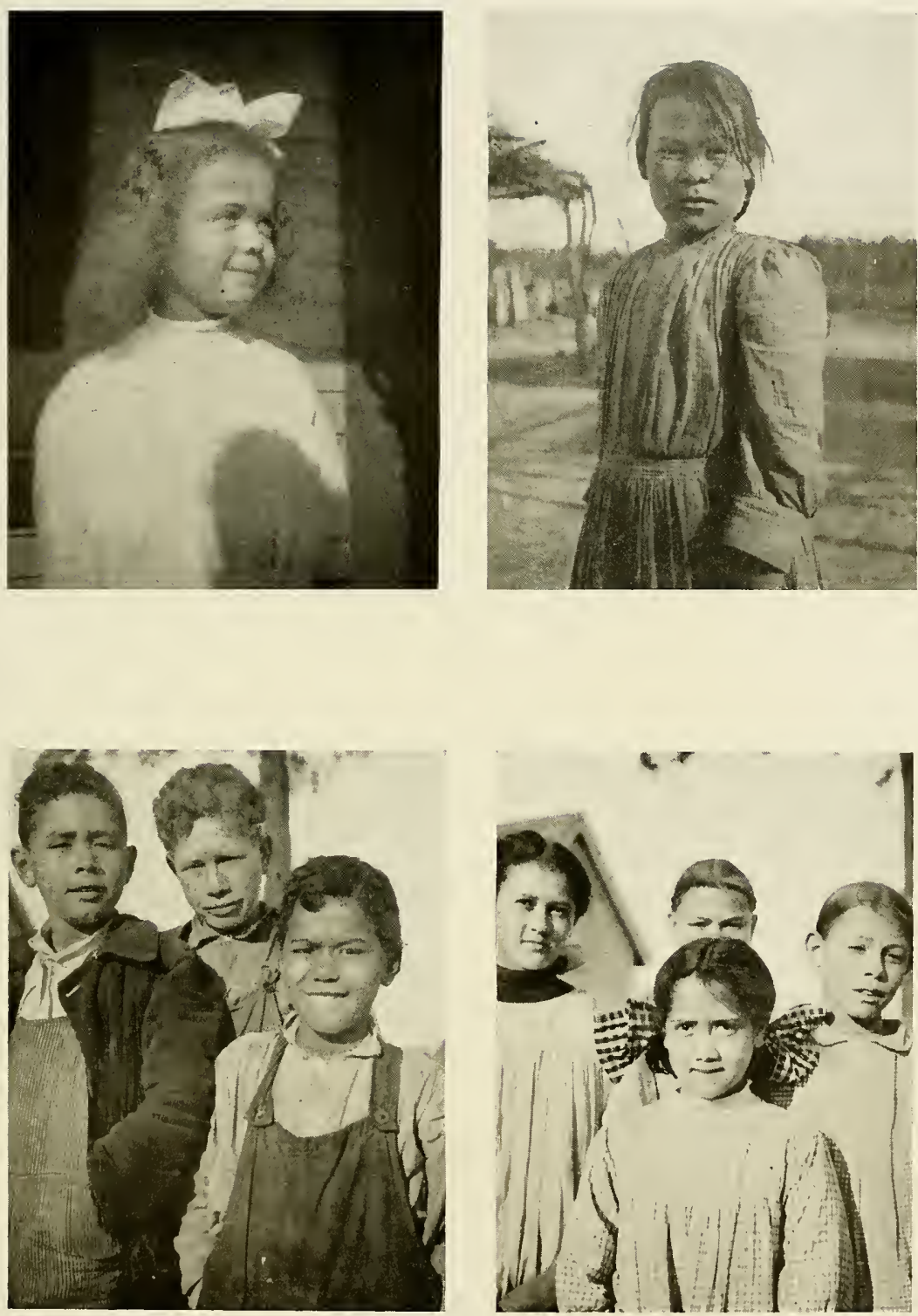

NANTICOKE CHILDREN 

the captured fish to the baskets; $b$ is the tapering entrance, $c, c$ the wings, and $d$ the runner. The distance from the shore varies. Fykes of heavier netting are used for terrapins, the collection in the Museum of the American Indian containing a terrapin fyke $8 \mathrm{ft}$. long, of heavy cord with an inch mesh. The lower left-hand figure of plate XVIII shows a scene along Indian river in February, I9I2, with a fyke, indicated by the poles, frozen beneath the ice.

From one of the old men of this community I obtained a fishhook with artificial bait and handline which he had made for himself so cleverly that it seems worthy of treatment as a product of native ingenuity. The whole device, except the hook itself, is of home make (fig. I0). From a piece of flat bone he has whittled the semblance of a small bait fish. A wire leader connects this, the hook, and the line. The float is of pine, plummet-shaped, and the line is wound on a corncob reel. This device the maker was using with great success in fishing for carp. He claimed to have thought of this arrangement by himself, the blind cupidity of the fish when hungry having suggested the artificial bait.

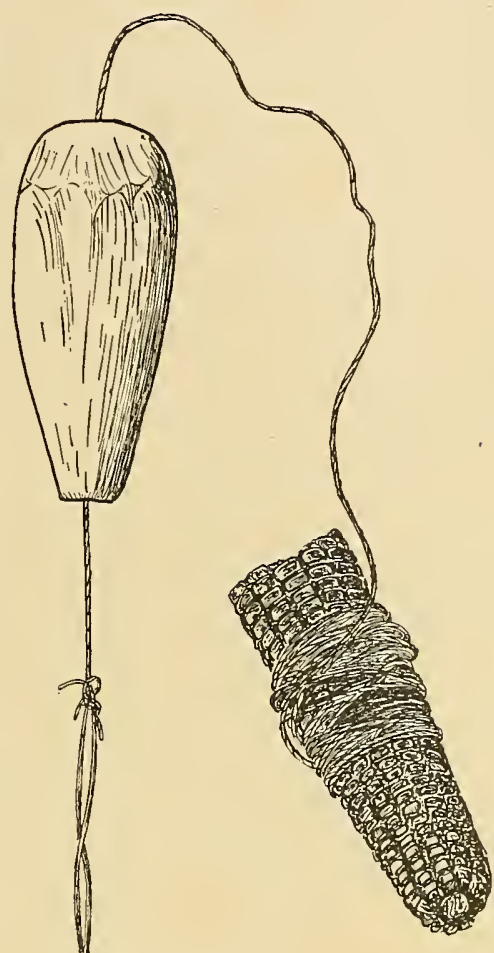

As adjuncts to the nets, there FIG. Io.-Fish-hook with artificial bait. 
are wooden floats made of pine, in the several shapes illustrated (fig. I I $a, c$ ), from 2 to 5 in. long and 2 in. wide. Stones are used for sinkers whenever they can be obtained in this sandy region; otherwise small bags of sand are ingeniously substituted. For hand-line fishing the floats are neater and somewhat pear-shaped (fig. II,$b$ ).

While agriculture and fishing were so prominent in the life of the Nanticoke, hunting seems to have been a minor activity in

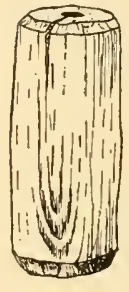

$a$

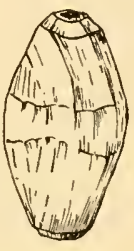

$b$

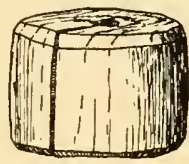

$c$

FIG. II.-Net floats. later years at least. In the extensive cypress swamp west of Millsboro, at the head of Indian river, game of various kinds was formerly abundant. Bears, deer (until about 25 years ago), raccoons, opossums, rabbits, quail, and squirrels were hunted. Strangely enough, though probably from climatic causes, the woodchuck and the partridge (Bonasa umbellus) are missing from this locality. The only vestiges of native hunting devices are the degenerated bows and

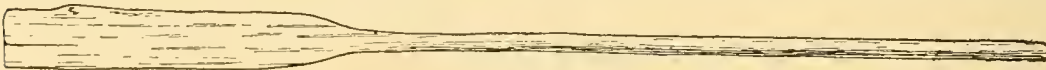

FIG. 12.-Paddle for fishing boat.

arrows, and two or three kinds of snares. The bows and arrows are now only rarely found among the boys, who use them in their play or for chasing rabbits and squirrels. In the memory of some

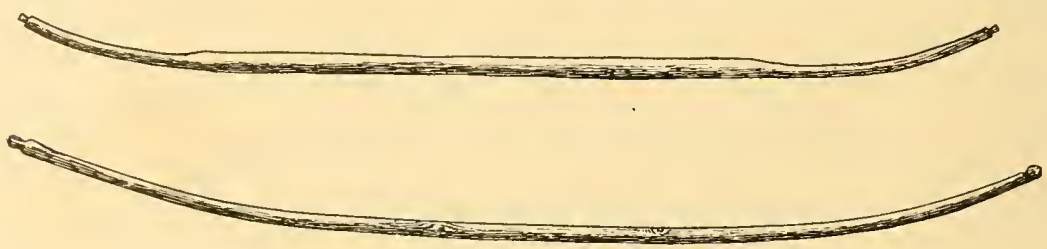

FIG. I3.-Bows.

of the older men, however, they were regularly carried by children who went hunting in the woods with their fathers, who of course 


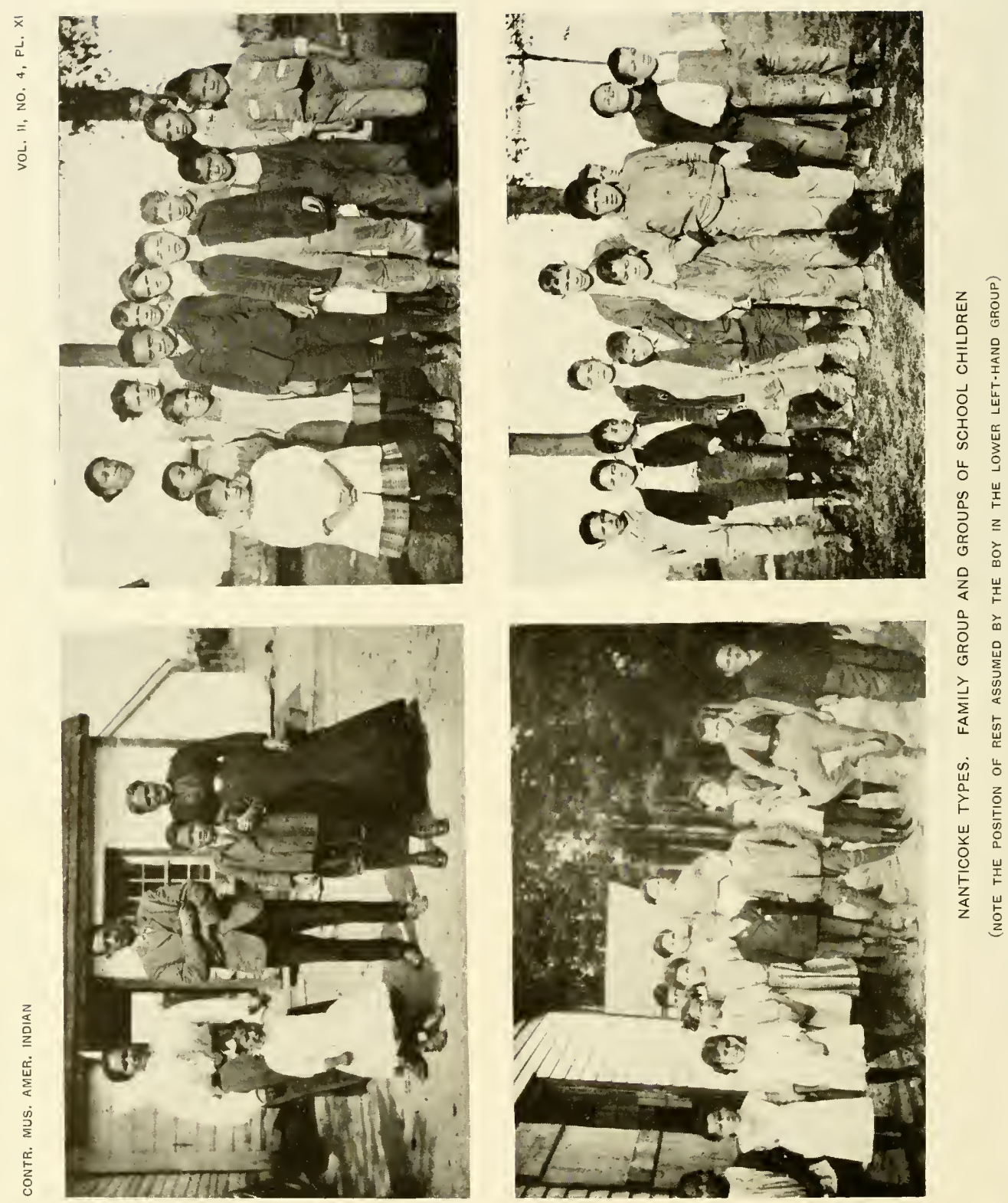

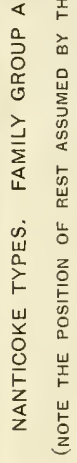


were armed with guns. The only bows available now are the small ones, $2 \frac{1}{2}$ to $3 \mathrm{ft}$. long, made of white cedar or oak-plain staves sometimes squared in section (fig. I3). The arrows, I7 in. long, are more interesting because they exhibit features that resemble those of the arrows of the Southeastern tribes. Here, for instance, a cone of tin forms the head (fig. I4), for shooting small creatures and even fish.

A common device for trapping rabbits and opossums is a box-trap made of a hollowed gum-log. From a single hollow log, eight or nine sections may be cut off to make as many traps. The back is closed with a piece of board, the front opening is provided with a drop door, as shown in the illustration (fig. I5), and a trigger attachment with dropping apparatus. An ordinary box is of :en used, but it is interesting to note that in the Nanticoke device there are found some features which differ from those of the common rabbit box-trap of the country boy. Some of these may be traced to local Indian origin.

Several choking or spring snares (fig. I6) are also interesting. The illustrations show all needed details. A slip-noose is attached to a bent sapling or pole. In FIG. I4.one variety the trigger-stick, attached by the middle to the string, is caught vertically in the crotch of a stick driven into the ground, where it is held by the bait-stick. In the other, the trigger holds in the notches by the pull of the string, the moving of the bait-stick freeing it from the notch. In both of them the loop is commonly supported upon three or four small forks, so that it rests in front of the bait, just beneath where the animal's head comes.

\section{OTHER INDUSTRIES}

BASKETRY

The basket-making of the Nanticoke is the survival of an old art, the methods and materials, as well as some of the present-day types, representing the more utilitarian side of the original industry. 
The Nanticoke nowadays make only the plain splint baskets for household and farm use, in a variety of sizes but of only one style. These are of the common, circular-bottomed twill (over-oneunder-one) weave, and range in capacity from about a quart to approximately a bushel. In the matter of the rims, the baskets show an interesting and significant peculiarity which will be figured later, though in all other respects their baskets would pass without comment in any of the Eastern Atlantic Algonkin tribes.

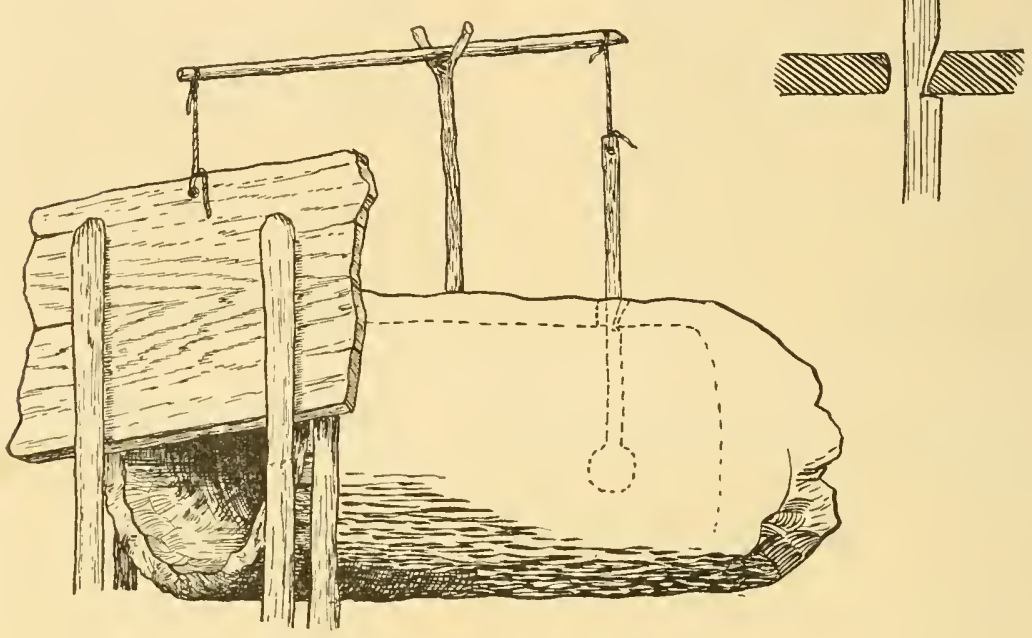

FIG. I 5--Gum-log rabbit trap.

The materials used are yellow pine (Pinus echinata) and white oak (Quercus alba). The trees are felled, and the splints loosened at one end of the log and pulled off by sheer strength without previous pounding or other preparation. With a knife the splints are next smoothed and thinned to the desired proportions, when all is ready for the weaving.

The bottoms are of two kinds, round and rectangular. In the former, the weaver begins with from twelve to sixteen standards, arranging them like the spokes of a wheel and weaving the splint filling spirally over-one-under-one; this is continued up the sides 

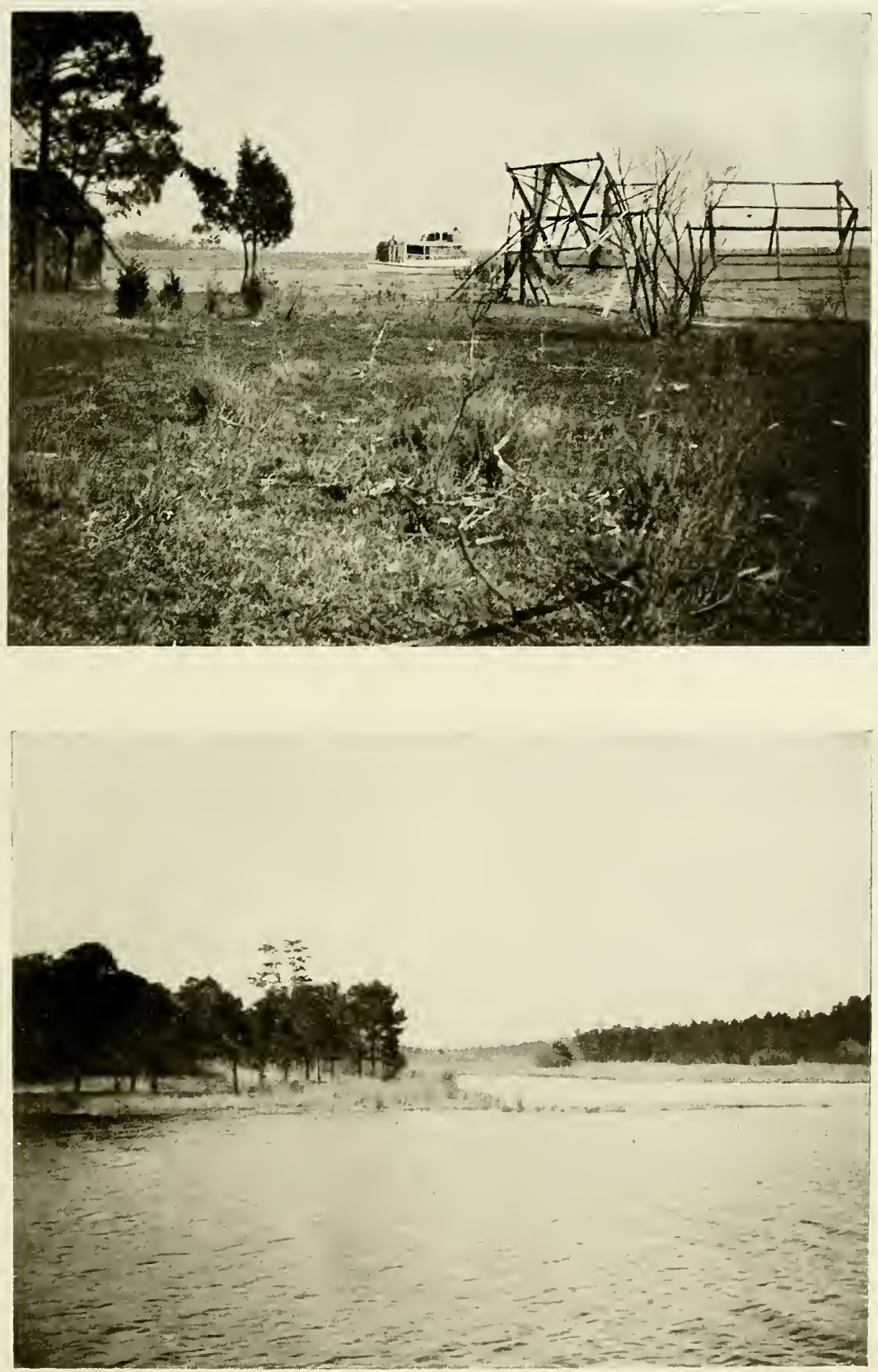

SCENES ON INDIAN RIVER, DELAWARE, SHOWING (UPPER) NET-REELS AND (LOWER) SEVERAL ARCHEOLOGICAL SITES 

to the rim. In baskets with rectangular bottoms, the pattern is of the common checkerwork type, the sides being as in the preceding.

In practically all respects there is nothing unusual in the baskets with the exception of the rim, where a local distinction appears. The wall of the basket being finished, every alternate standard is

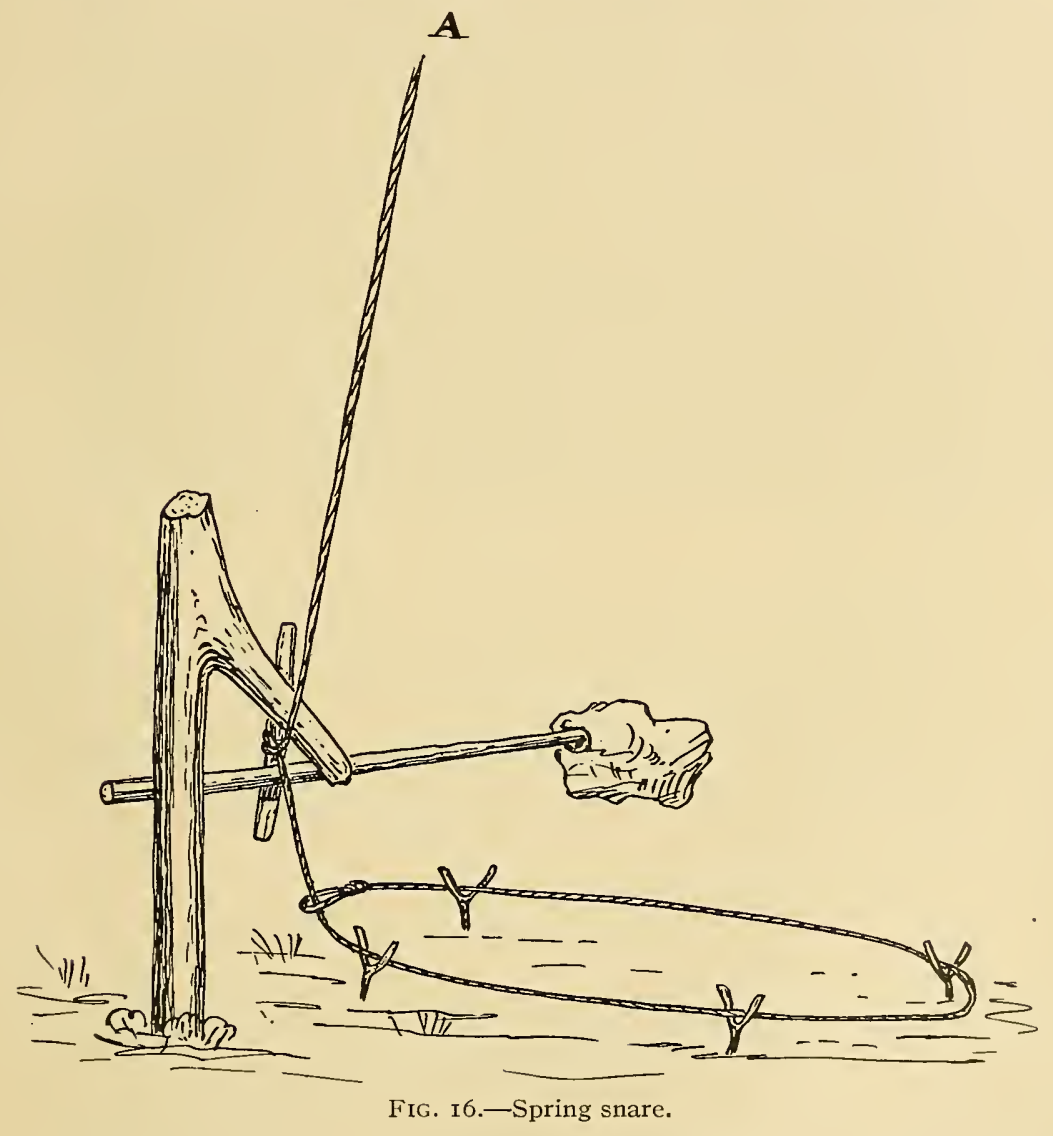

bent down and the other cut off. Inside and outside of this is a smoothed hoop, flattened on the inner face and rounded on the outer. Above and between these hoops is another, rounded, and the three are bound by a splint wrapping that passes continuously round the upper hoop and at every fifth or sixth turn comes down 
and encircles the inside and outside hoops. This feature is shown in figure 18. I have not seen anything like it, except in Malay basket rims and in some specimens from the Congo. Practically all the Nanticoke baskets have it.

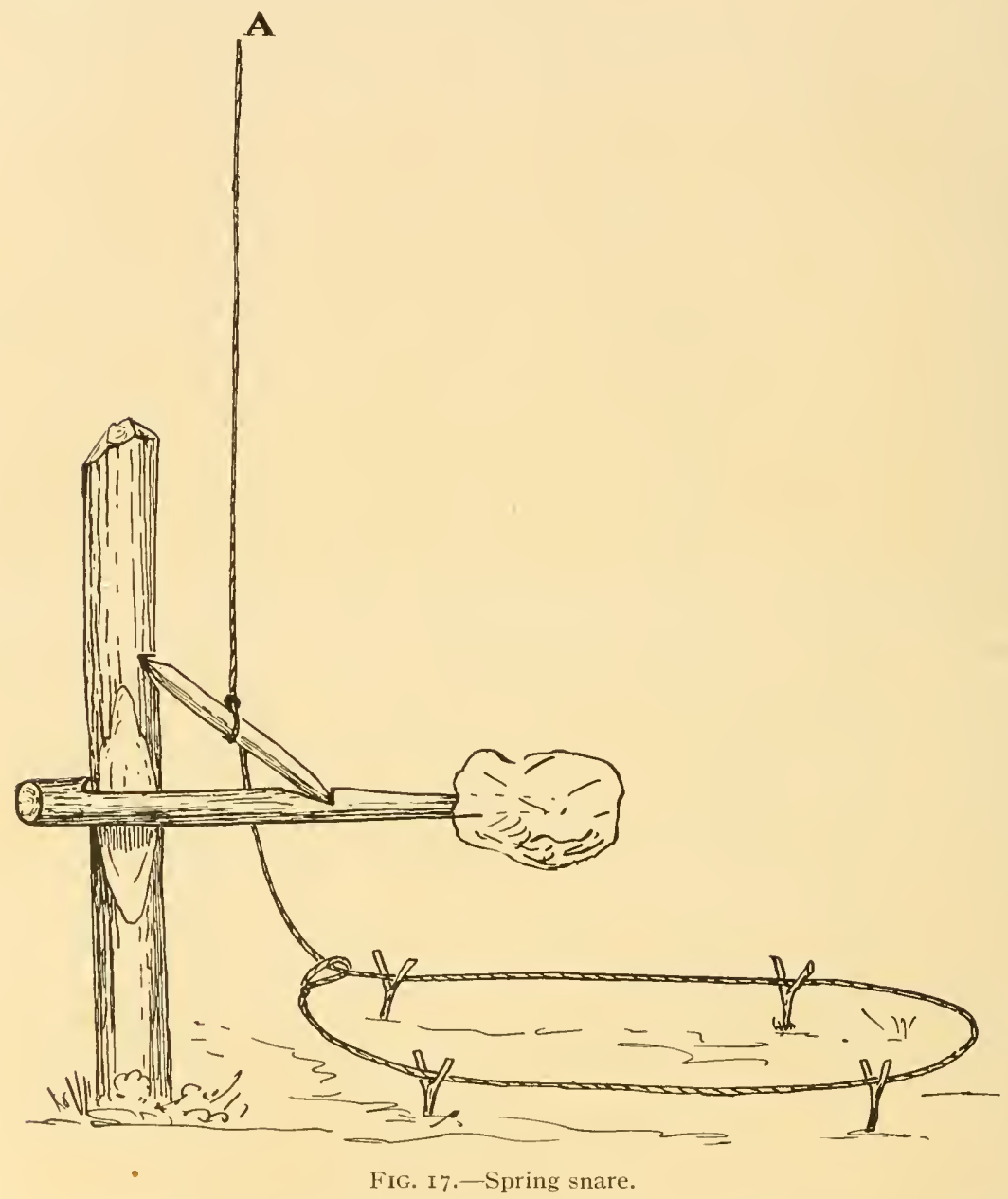

Generally speaking, the baskets are of two sizes. The larger ones $(\mathrm{pl} . \mathrm{xx})$ are either for regetables or for fish, and range from 8 to $16 \mathrm{in}$. in height and from 12 to $20 \mathrm{in}$. in width. The smaller specimens (pl. XIx) are provided with bales and are used for 

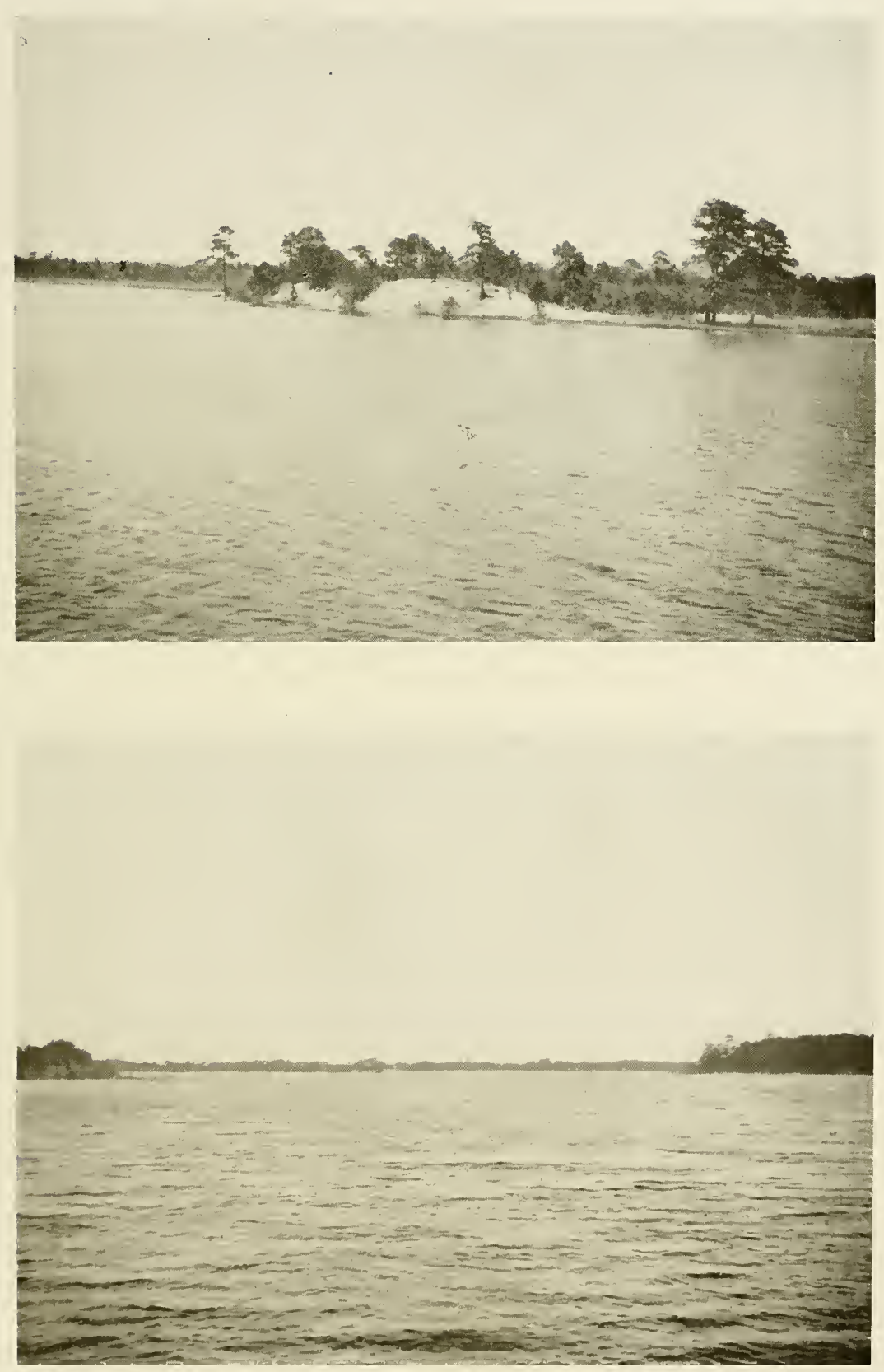

SCENES ON INDIAN RIVER, DELAWARE 

carrying or storing small articles, eggs, fancy-work, tools, etc. They average I $\mathrm{I}$ to $\mathrm{I} 2 \mathrm{in}$. high and 7 in. wide. Occasionally some attempt at decoration is made by dyeing one or two woof splints a dark color with pokeberry or other native dye.

Until a few years ago baskets woven of rushes were known.

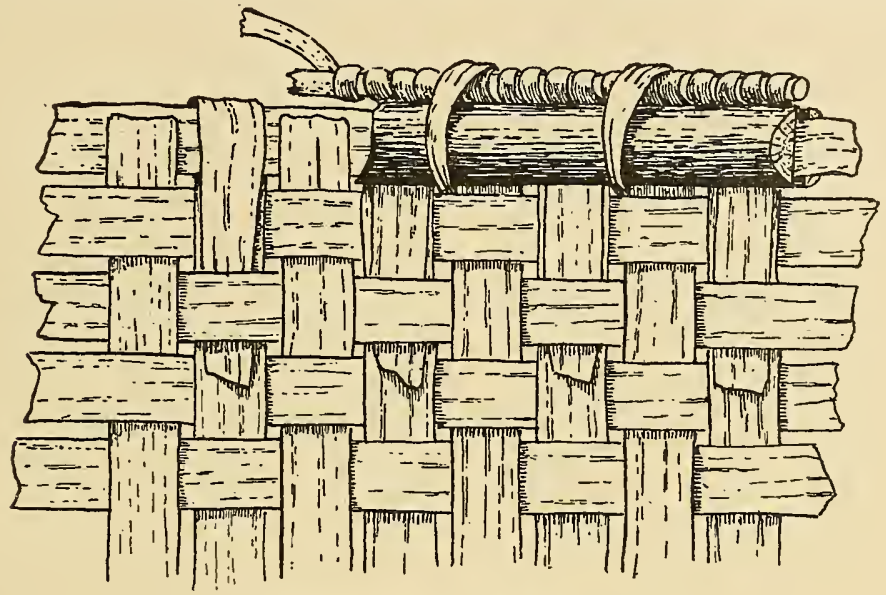

FIG. I8.-Detail of basket rim.

A rather interesting though degenerated fancy basket, obtained from one of the women of this community and said to be of a kind more common in times past, is constructed of corn-husks. Lengths of these have been braided and coiled spirally to form bottom and sides, the attachment sewn being of cotton. Around the sides are sewn loops of corn-husk to give an ornamental effect, a braided husk handle completing the receptacle. It is about 6 in. wide and 3 in. high (pl. xIx).

\section{DYES}

The following substances are used for coloring basket materials:

Poplar bark, boiled, gives a dark-brown color.

Crushed chokecherries give a black or blue color.

Pokeberry juice gives a pink color.

Wild indigo plant gives a dark-blue color.

Red-oak bark, boiled, produces a light-brown color.

Walnut hulls are boiled to produce a brownish dye.

Myrtle berries give various shades of purple, red, and dark brown. 


\section{MISCELLANEOUS}

Gourds are commonly raised among the Nanticoke, the bodies being used for drinking vessels or as receptacles for such things as seeds, salt, household odds-and-ends, work materials, and, in former times, food. Some examples are illustrated in figure I9. By cutting off the necks, different depths and shapes are obtained. Sometimes the rims were scalloped for ornament. Gourds in appearance
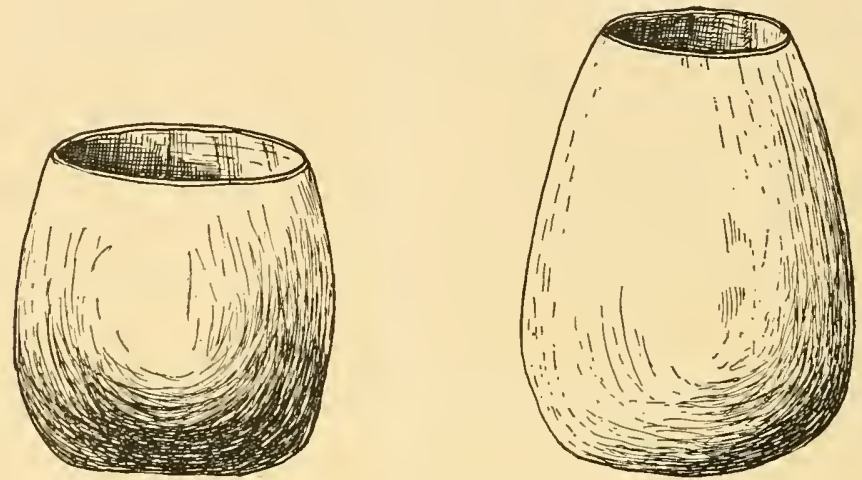

FIG. I9.-Gourd receptacles.

show a close resemblance to pottery, which they are said to have supplemented in use. Small gourds, with an aperture in one side, are commonly hung in trees as nesting places for bluebirds, martins, and wrens. Children use small gourds dried with the seeds inside for rattles.

Dug-out canoes have been obsolete for almost fifty years. Mr Clark says that those he remembers were pointed at both ends, were made of pine, and were about $\mathbf{r} 8 \mathrm{ft}$. in length. He states, as might be expected, that they were made by alternately adzing and charring the log. The canoe was poled, and paddled with a long paddle said to have been similar to the kind used with boats today (fig. 12). Canoes are called " pirogues."

An interesting method of hanging meat, especially salted pork, is without exception employed by all these people. In the meathouse of every farm are cross-poles supporting hams and other meat. The feature of note, however, is that the meat is always hung by a 

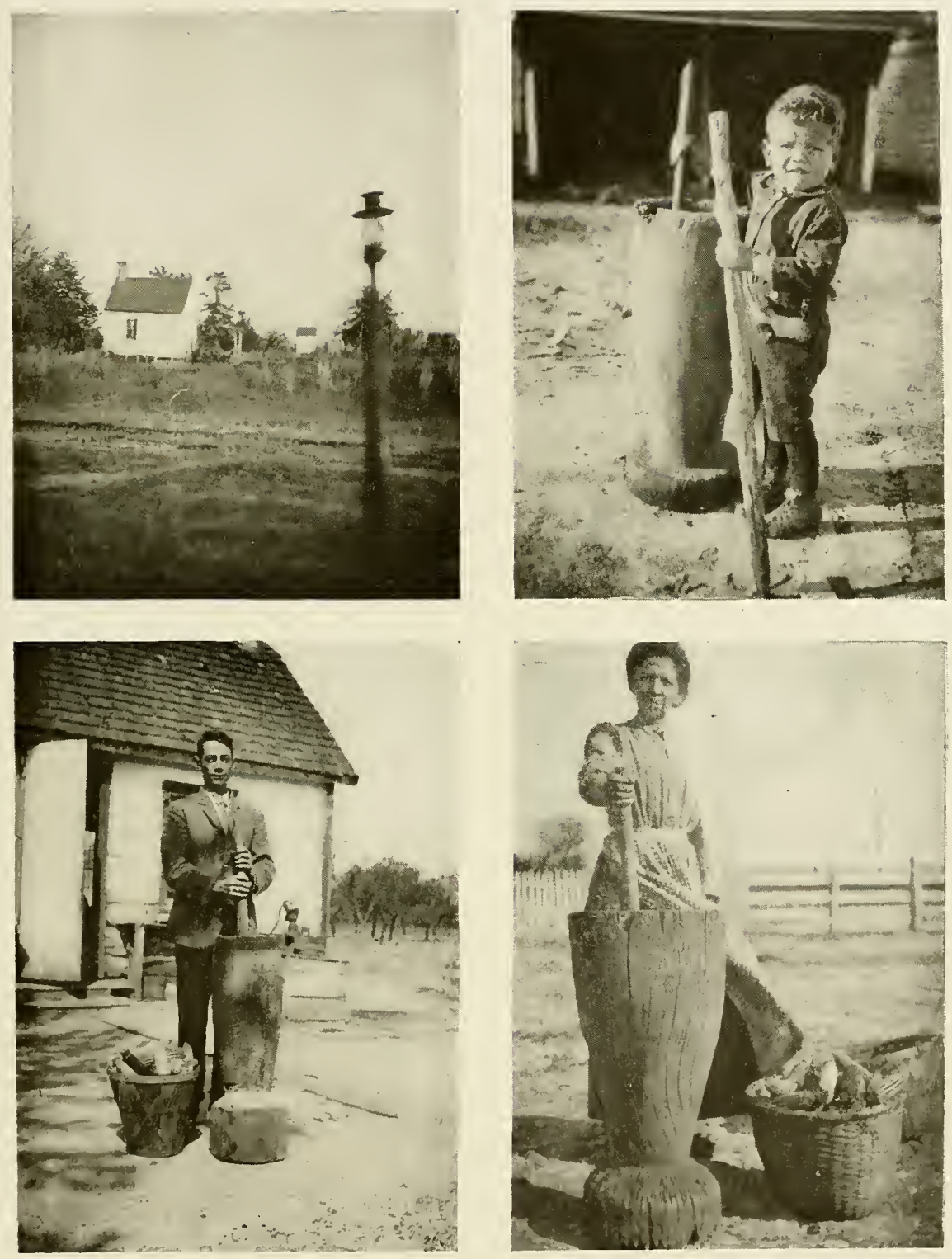

NANTICOKE HOMESTEAD, AND CORN MORTARS IN USE 

withe of Adam's needle, or yucca, not by rope or cord. The use of these fibers is evidently a survival of an aboriginal practice.

\section{Local Customs}

THE TURKEY SHOOT

The only Indian custom surviving in the community today for which we can find a parallel in the historical accounts of the region, is one known as the Turkey Shoot, or "Shooting Match." In autumn, generally in November, it is customary among the Nanticoke to hold gatherings at different farms where the women sew and gossip and prepare something to eat, while the men, armed with shotguns, repair to a spot in the field near the house. There a piece of stick is inserted in the ground and a line drawn about one hundred paces away. The man at whose home the shoot has been assembled provides discs of paper upon which any of the marksmen may have their initials written by paying a fee of five cents, which entitles him to a shot at the paper. Then a certain chicken or a turkey is indicated as the one to be shot for, those who wish to purchase a shot make payment and receive their slips, and then each takes a shot at his own slip which, at his turn, is fastened to the stick. The man who has made the best shot, as indicated by his slip, wins the bird. Years ago it was the custom to try to shoot the head off the bird. These "shoots"'are very much in favor in the community, serving as social gatherings for families living far apart. The ancient Nanticoke sport is thus described by Campanius: "The sachem causes a turkey to be hung up in the air, of which the bowels being taken out and the belly filled with money, he who shoots the bird down gets the money that is within it." 1

\section{WEDDING SERENADE}

Among other rural customs in the community the Wedding Serenade is well known. On the night of a marriage a crowd of men and boys gather at the house of the wedding and serenade the bridal pair with singing, and an improvised orchestra of cow-bells,

1 Francis Vincent, A History of the Slate of Delaware, vol. I, p. 7 I (quoting Campanius, p. I28), Phila., I870. 
horns, and the like. If the groom does not invite them in and treat them to food, they ride him round the house on a fence-rail.

\section{GAMES}

Besides the ordinary country games of white children, the Nanticoke play some group games which may have an element or two of individuality. One is "Bear-in-the-ring" (see pl. $\mathrm{xx}$ ). Within a circle of boys holding hands stands another boy who is the "bear." His object is to break through the ring and escape. Should he succeed, the one to catch him has the privilege of being the "bear" next time. Another game is "Toad-in-the-meadow."

Cat's-cradles are generally well-known among these people. The figure known among the Southern Indians as "crowfoot" is common here also as "crow's feet." Another is Job's Coffin and is regarded as symbolic of the constellation of that name. String-figures in general among the Nanticoke, it is interesting to note, are regarded as representations of star groups.

\section{FOLKLORE}

\section{MEDICINE PRACTICES}

The following amulets and herb cures were learned of among these people. Knowledge of them seems to be quite generally distributed among both sexes; the idea prevails, however, that there are some people who are more gifted in their ministrations than others. For instance, there are those who have the gift of removing sickness by their will. The seventh son or daughter is thought to possess some such magic power and the knowledge of useful medicines. ${ }^{1}$ Then others there are who have the power to cast "spells" on people.

A string or necklace of deerskin will prevent the wearer from getting whooping-cough.

A necklace of kernels from an ear of red corn will protect the wearer from nose-bleed. (See pl. xvir.)

A dried spider wrapped in cloth and put in a thimble worn round the neck will also prevent nose-bleed.

${ }^{1}$ A belief almost universal among the Eastern Indians as well as among the whites. 


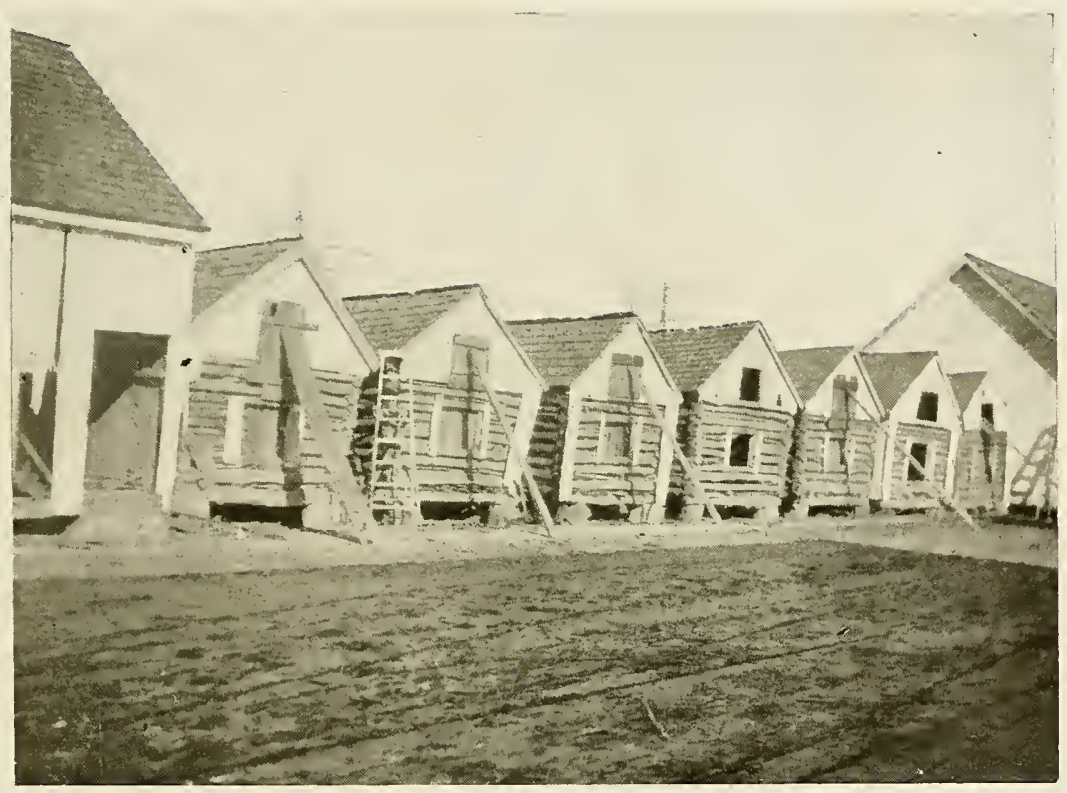

NANTICOKE CORN-CRIBS

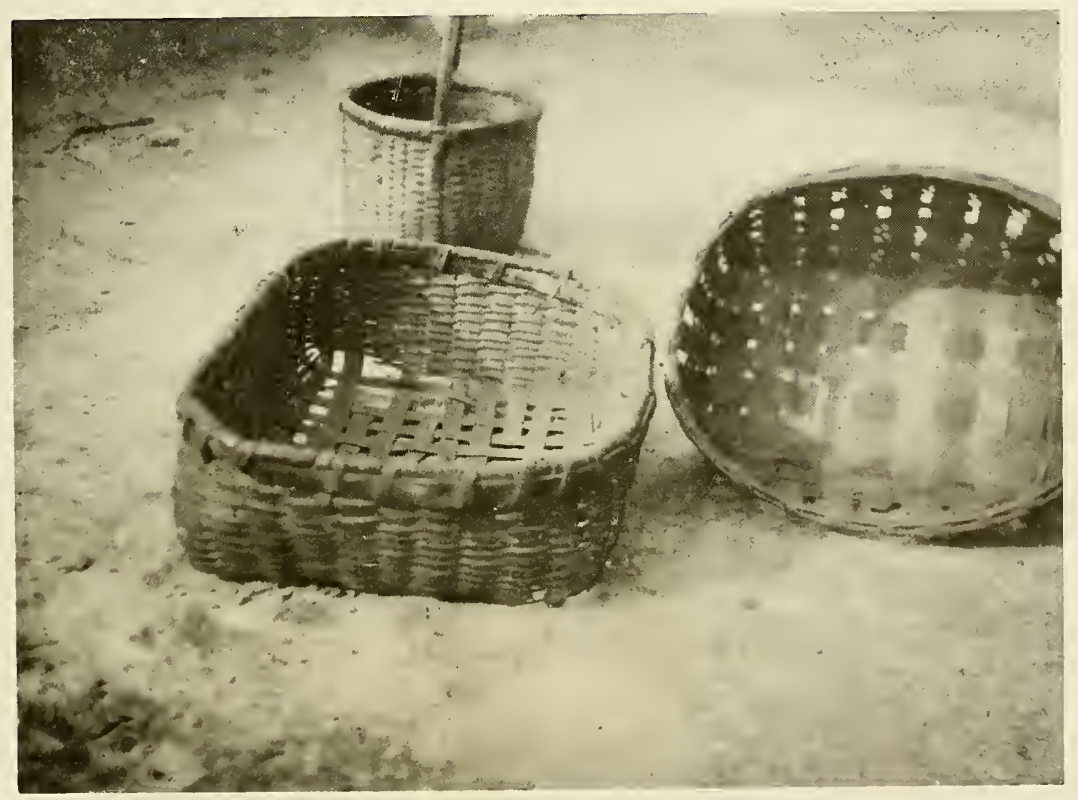

FINER BASKETS OF AN EARLIER PERIOD 

For curing a lame person, secure a worm, put it in a bottle, and hang the bottle up until the worm decays, then rub the matter upon the lame limbs.

To prevent fevers during summer, it is said, chew the petals of the first hepatica flower which you see in the spring. The hepatica plant (Hepatica triloba) is called "chills-and-fever plant."

Horsemint (Cunila origanoides) is brewed for colds.

Calamus root, "muskrat root" ${ }_{1}$ (Acorus calamus) is used for colic and for babies with colds. A tea is usually made. Or a piece of root may be carried about to be chewed. Mothers chew it and blow into infants' mouths to stop pain or to sooth them to sleep.

Mullein (Verbascum thapsus) leaves make an excellent poultice for fevers. Roll them out, dip them in vinegar, wring them out and bind them to the back of the neck, forehead, wrists, and soles of the feet. Keep wet with vinegar.

Wild indigo plant (Baptisia tinctoria) and poplar (Populus deltoidea) brewed together make a good lotion for sprains.

Pellets of pine tar (Pinus echinata) make a fine cathartic and are good for lame back.

An eel-skin is worn around parts affected with rheumatism.

Certain persons having the power can charm away warts by their spittle.

Chills likewise can be "promised" 2 away by a healer or witch.

Cuts are healed by covering them with cobwebs. In such a case a silver dollar is also bound over the cut. Soot likewise is used to heal cuts.

Blow tobacco smoke in the sufferer's ear to relieve earache. ${ }^{3}$

For a pain in the stomach, blow tobacco smoke in a cup of water and drink it.

Tobacco smoke blown in the baby's mouth will relieve its pain.

Prickly-pear (Opuntia opuntia) rubbed on warts will remove them. Inflammation may also be drawn from stings or bites by applying a split prickly-pear joint.

\footnotetext{
1 Incidentally similar to the Wabanaki name.

${ }^{2}$ Made to leave by promising the subject that they will go.

${ }^{3}$ Also a Malecite remedy, and known to the Mohegan.
} 
For chicken-pox, place the afflicted child in front of a chickenhouse door and let the chickens fly out over him.

For sore throat, place the bent thumb in the patient's mouth and press his jaws as far apart as possible for five minutes.

For nose-bleed, place a cobweb up the nostril. Also drop a bunch of brass keys down the back.

A tea brewed of skunk cabbage leaves (Spathyema foetida) will cure a cold.

To cure chills, take a stick and cut as many notches in it as you have had chills. Then go to the stream that flows to the east throughout its course, throw the stick in to the water over the left shoulder, and walk away.' The chills will leave in a day or two.

To cure warts: Pick up a stone at a cross-roads and rub on the wart as you walk along. Throw it over your left shoulder and walk straight to your destination without once looking back. The wart will disappear in three or four days.

To cure backache: Wear the skin of a blacksnake round the waist. The snake-skin must be removed whole from the living snake. (One old man is said to have obtained a fresh skin every spring and to have worn one of these constantly.)

A woman who marries but does not change her name (marries a man of the same name) can steal bread from her neighbors and give it to children to cure whooping-cough. She may even ask a friend to leave some bread where she can take it without being seen. A variant of this says that it is the bread stolen from a woman who does not change her name that will effect the cure.

For whooping-cough, take as many roaches as there are children afflicted and name each after one of them. Then each child puts the roach named after him into a bottle and corks it tightly. When the roach dies the disease will leave the child. But be sure that the patient's bowels are kept open or the charm may react and kill him.

The following verse of Scripture will cure nose-bleed; but it can be told to or said over only a person of the opposite sex. (Ezekiel, I6:6.) "When I passed by thee I saw thee polluted in thy blood and I said unto thee Live! and thou didst live in thy blood: yea thou didst live in thine own blood." 


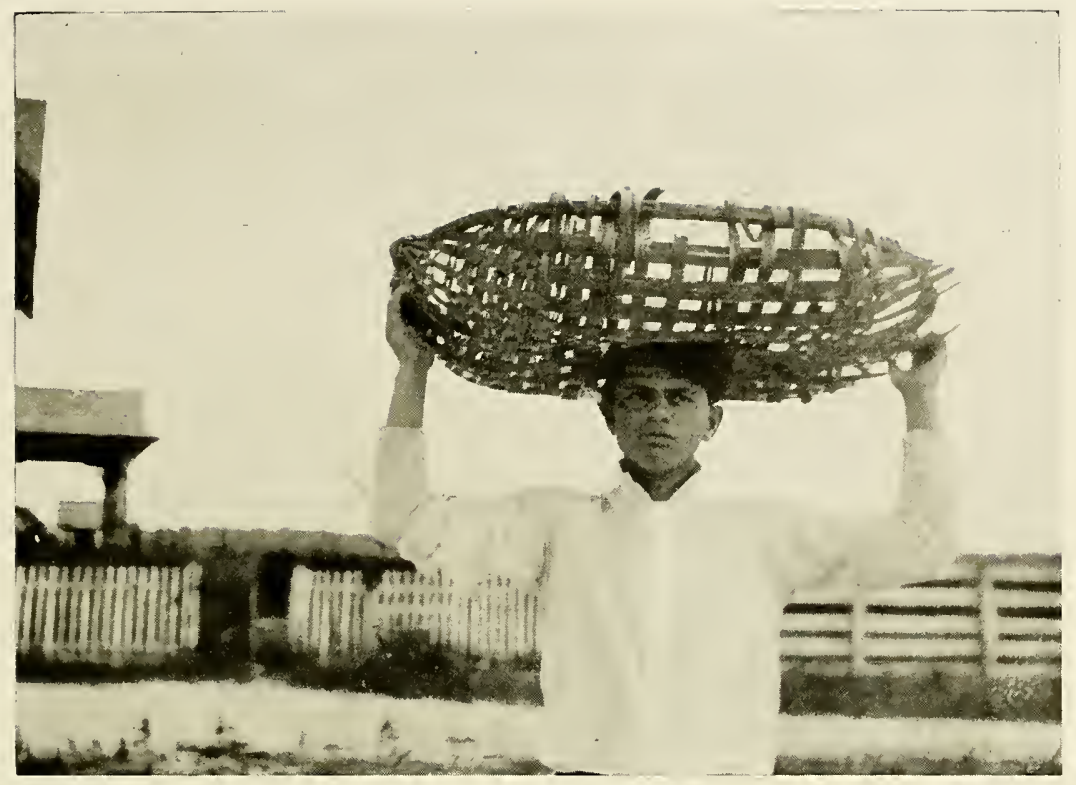

LARGE FLAT BASKET

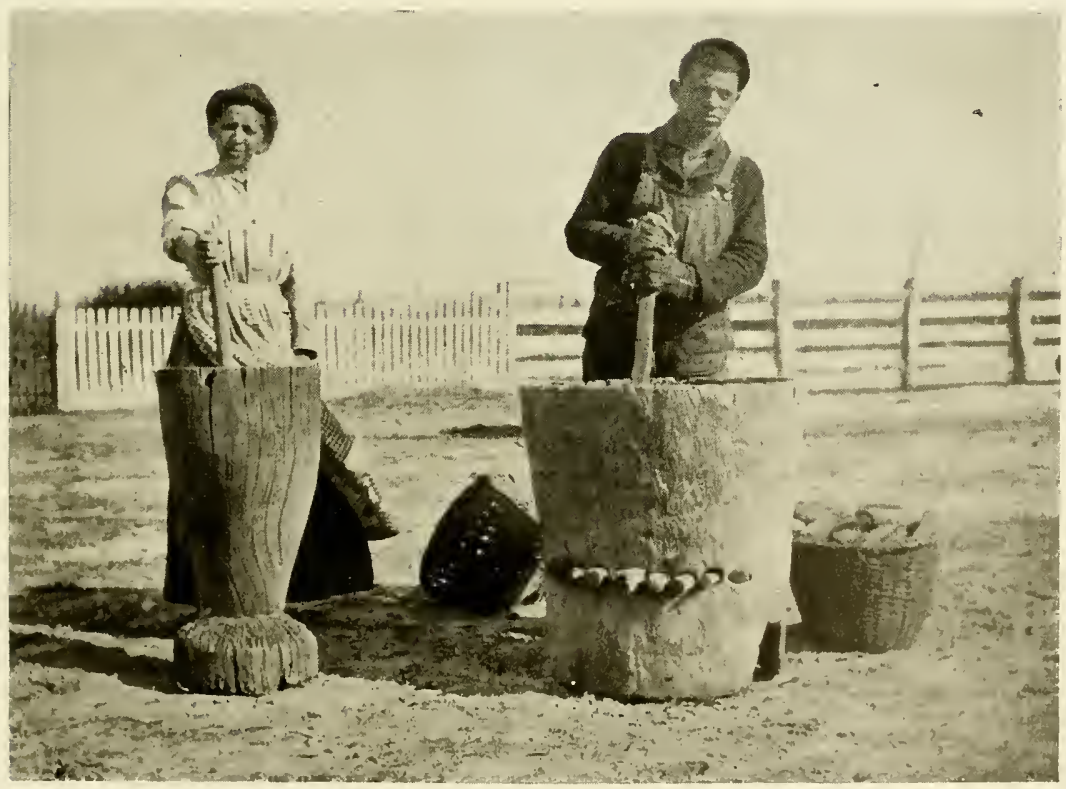

NANTICOKE CORN MORTAR AND "SHELLING MORTAR"' IN USE 

Cure for croup: Stand the child against the door-jamb and mark its height. When the child outgrows the mark it will be cured.

Cure for frost bite: Bind an animal's bladder on the affected part.

Several plants have local folk names, although no particular efficacy is ascribed to them. Milkweed (Asclepias tuberosa) is called "frog's milk." Wild gooseberries (Grossularia sp.) are called "Devil's berry" because when they ripen one at a time and fall off during the night, they say that the Devil picks them off.

Sassafras (Sassafras sassafras), pronounced locally as "sarsafack," is made into a tea and drunk in spring to ward off fever and ague, and to cool the blood. It is thought that fever and ague are brought on by going barefoot or swimming in the river too early in the spring. The ailment is very common in this region.

The leaves of a plant called "fish weed" are chewed for worm troubles. Snake-root (A ristolochia serpentaria) is steeped and given for the same ailment. ${ }^{1}$

Pipsissewa (Chimaphila maculata) is steeped and drunk by the cupful to cure ague.

The leaves and stems of a plant called "King Cole oil weed" are good for poultices.

Balsam plant (Impatiens biflora) is steeped and made into a poultice for burns.

Burdock (Arctium minus). Leaves steeped and applied to boils.

Arrowroot (Peltandra virginica) is grated and fed to babies. It resembles corn-starch when mixed with milk.

Pennyroyal (Hedeoma pulegioides) and Tansy (Tanacetum vulgare) are both used as sudorifics. Pennyroyal is also considered an excellent kidney and liver medicine.

Myrtle (Leiophyllum buxifolium) berries are made into wine and tonic.

Wild Thyme (Thymus serpyllum) and Boneset (Eupatorium perfoliatum) steeped together are drunk for chills and fever.

For convenience of reference the Nanticoke-Moor remedial plants are presented in the following form, local names being marked with an asterisk.

\footnotetext{
1 Snakeroot is also a Penobscot and Mohegan remedy.
} 
Hepatica (Hepatica triloba)

Horsemint (Cunila origanoides)

Calamus (Acorus calamus)

Mullein (Verbascum thapsus)

Wild Indigo (Baptisia tinctoria)

Poplar (Popultus deltoidea)

Pine (tar) (Pinus echinata)

Prickly-pear (Opuntia opuntia)

Skunk Cabbage (Spathyema foetida)

Sassafras (Sassafras sassafras)

Milk-weed (Asclepias tuberosa)

Wild Gooseberry (Grossularia sp.)

*Fish Weed (sp. ?)

Pipsissewa (Chimaphila maculata)

*King Cole Oil Weed (?)

Balsam Plant (Impatiens biflora)

Snakernot (Aristolochia serpentaria)

Burdock (Arctium minus)

Arrowroot (Peltandra virginica)

Pennyroyal (Hedeoma pulegioides)

Tansy (Tanacetum vulgare)

Myrtle (Leiophyllum buxifolium)

Thyme (Thymus serpyllum)

Boneset (Eupatorium perfoliatum)
Fever and chills

Colds

Colic

Poultices

\}Sprains

Cathartic

Cure warts, frost bite

Colds

Fever and ague "Frog's milk" "Devil's berry"

Cure worms

Ague

Poultices

Poultice for burns

Cure worms

Boils.

Baby food

$\left\{\begin{array}{l}\text { Kidney, liver } \\ \text { sudorific }\end{array}\right.$

Tonic wine

Fever and chills

\section{WEATHER SIGNS}

Killdeer plovers ("kildee") flocking and calling in the morning when it is calm are a sign of coming wind.

Killdeer plovers as well as some other birds are thought to speak certain words. The killdeer says, "Wind blow, wind blow!" This is another sure sign of the coming of wind.

The flight of wild geese is also regarded as a sign of wind approaching.

If the chickens stay out in the rain and continue feeding you may expect it to rain for a long time. They know that it is going 



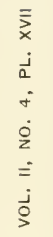
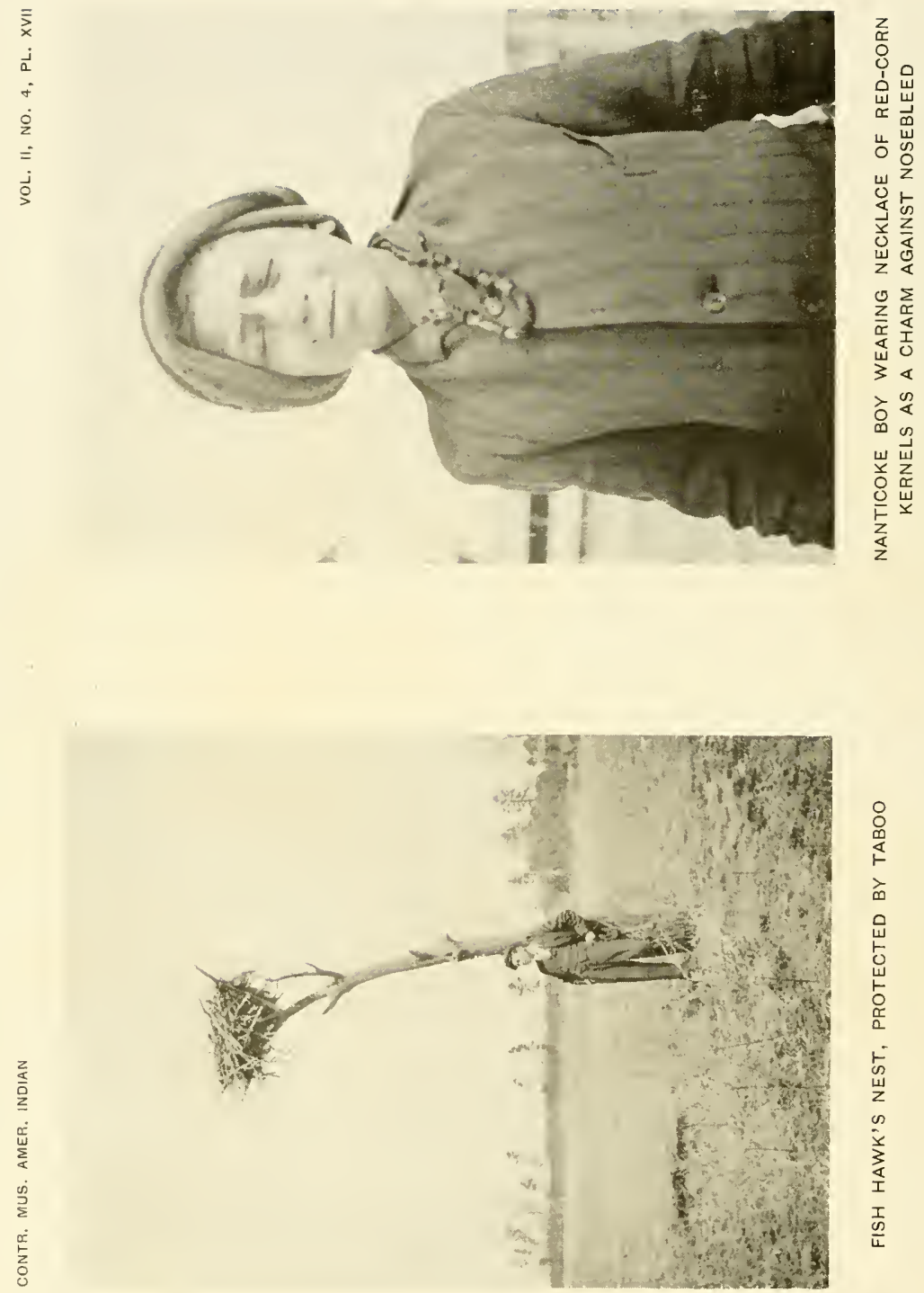
to rain and want to get something to eat before they go to shelter. If they run for shelter when it begins to rain, the rain will not last very long. They know they can feed later on, so do not stay out in it.

When you hear the surf (the ocean is nine or ten miles to the eastward) you may expect rain the following day. (This denotes an east wind.)

When crows or blackbirds flock in a field it is going to rain.

When hogs become restless, grunt, and pick up sticks, cobs, etc., as though they are going to make a nest or a bed, a storm is coming.

When it rains and the sun is shining it will rain again the next day.

Where the ends of the Milky Way appear to rest on the horizon is the direction from which the wind will blow the next day. ${ }^{1}$

The sun-dog is a sure sign of a coming storm.

If you kill a snake and throw it into a tree, it is a sign that it will rain the next day if the carcass hangs in the branches, but if it falls through the branches the next day will be clear.

\section{MISCELLANEOUS SIGNS, OMENS, AND BELIEFS}

If you mock a mourning dove, some time he will burn you. ${ }^{2}$

The cooing of the turtle-dove indicates the direction where your lover is. ${ }^{3}$

The whippoorwill's first cry in spring is the sign that it is time to plant corn.

A black animal seen crossing one's path at the beginning of any venture is a sign of bad luck. Turn back and choose another time. ${ }^{4}$

A falling star is the sign of disappointment.

When the new moon is first seen, take out your pocketbook and shake it toward the moon for good luck.

\footnotetext{
1 Known among the Indians as far as the Montagnais of Labrador.

${ }^{2}$ Resembles the Wabanaki belief about mocking the screech owl.

${ }^{3}$ Known among the Muskogians and Yuchi.

${ }^{4}$ Resembles an Ojibway and Wabanaki belief.
} 
The Jack-o'-my-lantern is thought to be a kind of spirit which is likely to follow people and cause misfortune. To prevent this, people turn their pockets inside out when they see one. An informant claims to have seen a number issuing one night from the stump of a dead tree.

Ringing in the ears is known as "death bells", and announces the death of some friend or relative.

On New Year's day it is the custom for men to go visiting, the first to come to the house receiving fifty cents. But for a woman to come to a house on this day is an ill omen.

Like storks in Europe, fish-hawks (Pandion haleretus carolinensis) are venerated by the Nanticoke. It is a sin to kill them or to disturb their nests. The fish-hawks respond by building their nests near habitations, generally in open fields among the limbs of a dead tree, sometimes as low as fifteen feet from the ground, and returning to them year after year. These huge nests are fairly common and become the abode of many small birds as well. (See pl. XVII.)

Buzzards also are never molested.

If a scorpion lizard (locally "scorpion," Sceloporus undulatus) gets on a person and manages to run completely round the body, the person will die.

To win the girl with whom you are in love: Cork an empty bottle and take it to a stream that flows to the east through its entire course. Tie a string round the neck of the bottle and fasten the other end to a limb or a bush overhanging the stream. Then put the bottle on the water so that the stream pulls it along until the string becomes taut. Draw with a stick in the sand a picture of the girl. Anything will do provided it be your best and your mind is intent upon it so that you really mean it to represent her the best you can. Then go away and leave it. As the string holds the bottle so she will cling to you. But if the string breaks, then she will break away from you.

To win the one with whom you are in love: Go to a well at noon on the first of May and hold a mirror so as to get the reflection of the water below. In the mirror you will see the image of the girl 


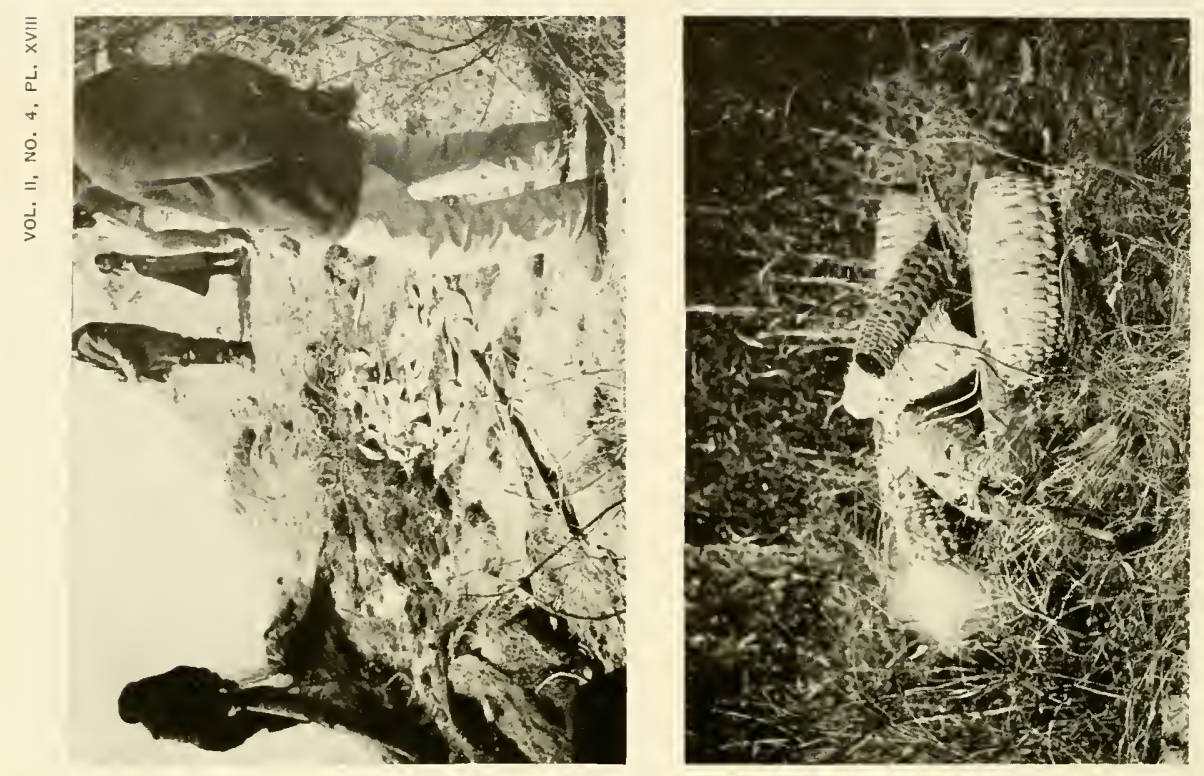

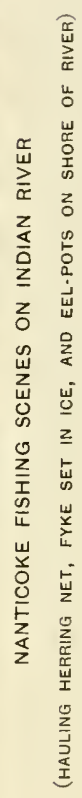
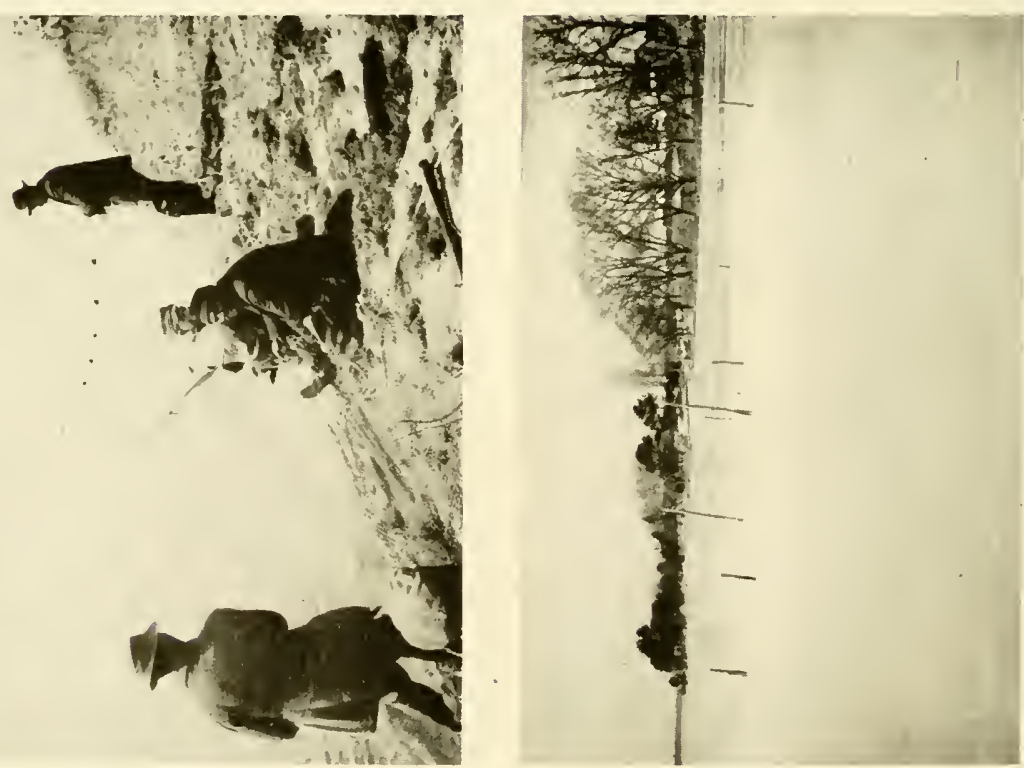
or the boy you are going to marry. If you are not to marry at all you will see a coffin.

Two of the same sex are required in performing the following love charm: Boil an egg hard and let it stay in the water a day. Then each breaks it, takes out the yolk, and fills with salt the space left by its removal. Eat the white of the egg and the salt without water and without saying a word. Walk out of the room backward, go upstairs backward, and get in bed backward. In a dream the girl or the boy you are to marry will come and bring you a drink of water. During all this time and until morning of the following day not a word must be spoken.

The Midnight Supper: Only two persons of the same sex can perform this charm. At midnight, with the lights turned very dim, two people of the same sex sit at the opposite ends of a table and eat ash-cake [see page I4]. If you are going to marry, the form of the person you will wed will appear to come to the door and walk straight across the room. If you are not to be married, a coffin will come and rest alongside of you.

To cause a person's death: Get a piece of his hair and bore a hole into a pine tree when the sap is down; that is, before March 20. (Any time between September 20 and March 20 will do. The sap begins to run up about March 20.) Put the hair in the hole and plug it up. The sap will come up and the person whose hair has been placed there will die within a year.

If a hen crows it is a sign of bad luck and it should be killed.

A rooster crowing at the door denotes a visitor.

When a turtle dove is heard mourning, sit down and take off your shoe, and you will find a hair in it the color of your future wife's hair.

The small eggs often laid by hens are called "latter eggs." They denote that the hen is through laying for the season.

To hand a person a closed knife will bring bad luck. The knife should be opened.

When a child's umbilical cord is severed, it should be disposed of by burning, lest it bring bad luck. ${ }^{1}$

\footnotetext{
${ }^{1}$ Incidentally similar to Penobscot.
} 
Reptile Lore.-The red-headed skink (Eumeces) is called "woods bitch" and is thought to be poisonous. The male fence lizard (Sceloporus undulatus) is called "scorpion" and is thought to be poisonous because it has a blue throat, while the female, which has no blue on the throat, is called "lizard" and is not considered poisonous. Children capture these lizards by means of a noose of long, tough grass, called "lizard grass," and play with them as though they were little horses. They say that the lizard is not afraid of "lizard grass" and will permit himself to be noosed with it. Salamanders are all considered to be full of venom and are thought frequently to cause the death of hogs who have eaten them in the woods. Cats are also said to eat lizards in the spring and to become very thin as a result; they are then given a quantity of fat to eat, which causes them to get relief from the poison. The water snake (Tropidonotus), the hog-nosed snake (Heterodon), known locally as the "bastard hornet snake" (bastard, "not real"; hornet, "horned": "false horned snake," in the local dialect), the "field wiper" (field viper), a general name for field snakes, are all erroneously considered venomous. The black racer (Bascanion) is the only snake known correctly to be harmless.

Local snake-lore asserts that the "field wiper" bites itself and dies of its own poison; that the copperhead emits a smell like cucumbers; that a blacksnake-skin worn round the waist will cure rheumatism; that there exists a hoop snake which can take its tail in its mouth and roll like a hoop; that the blacksnake can suck a cow's udder; that if a dead blacksnake is hung upon a tree it will rain soon, perhaps "before you get home"; that the first thunder in spring awakens the snakes from their winter sleep, and that when a snake is killed its mate comes to seek the remains.

\section{Archeology and Local Tradition}

In Indian River Hundred, which lies on the northern shore of Indian river, the Nanticoke point out a number of archeological sites of which they have knowledge from their old people. From Millsboro eastward, following the shore, are almost continuous vestiges of camp-sites which lie up on the sandy banks of the river. At 


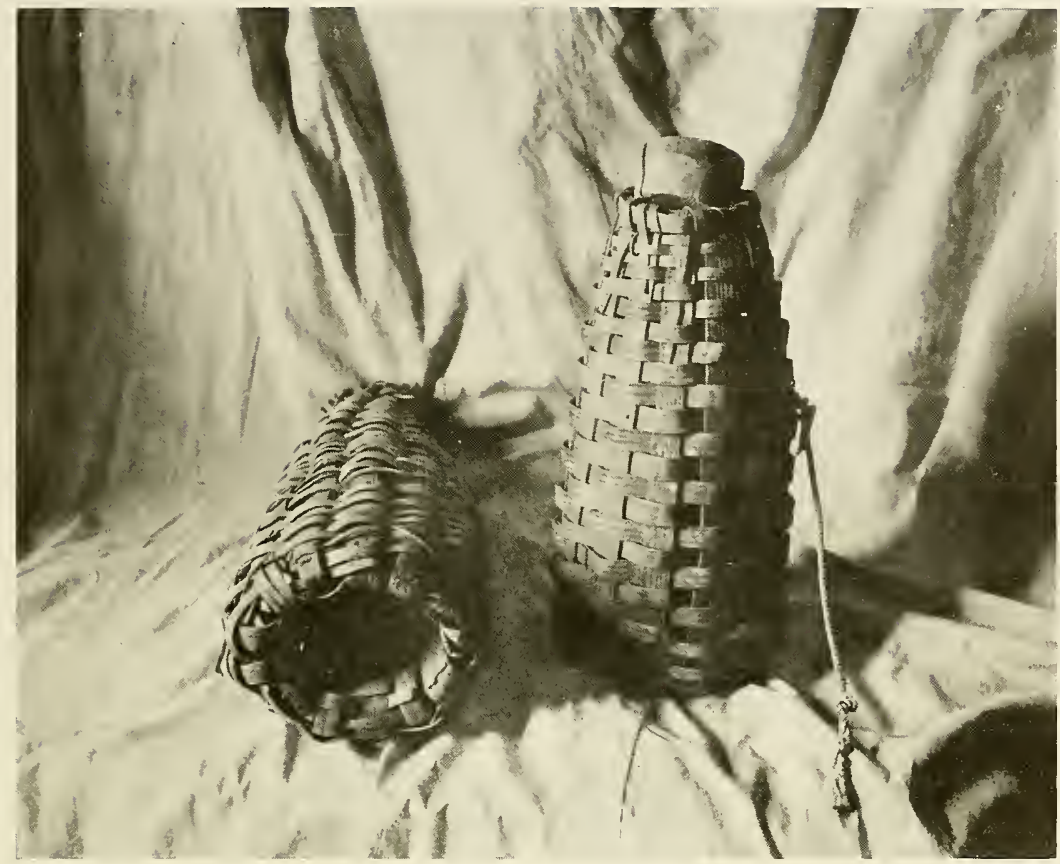

NANTICOKE EEL-POTS

(THE SPECIMEN AT THE LEFT IS MADE OF WHITE OAK, THE OTHER OF PINE)

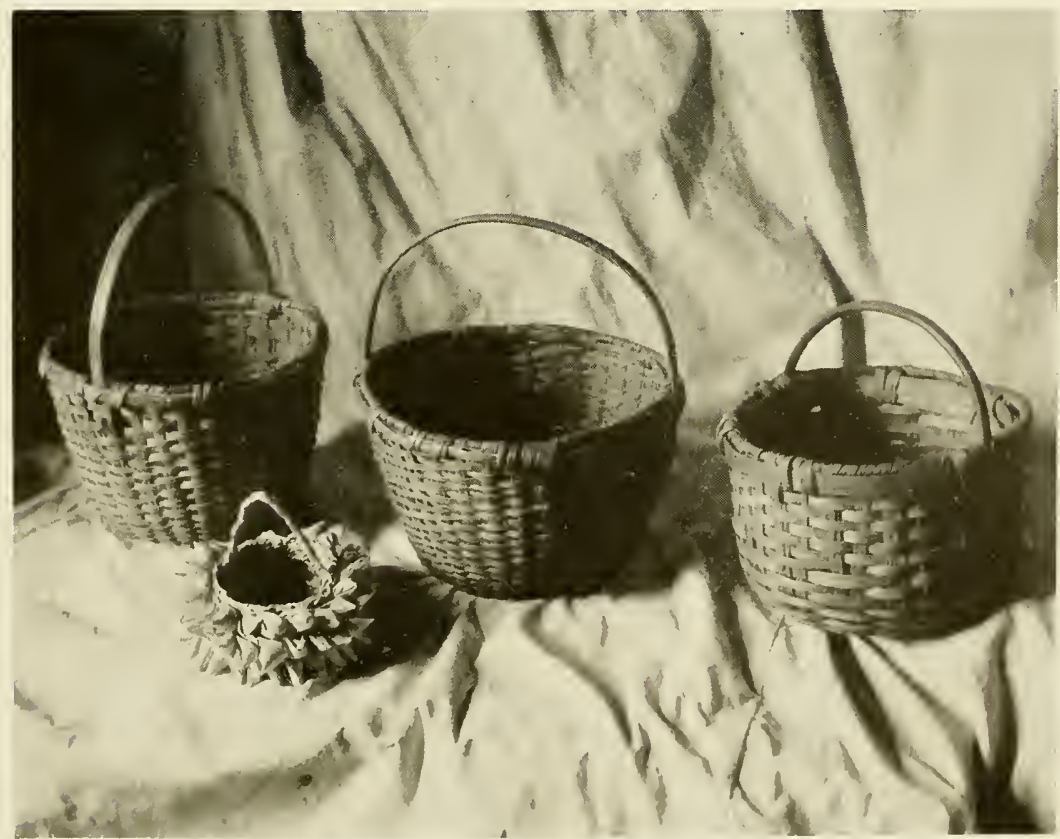

NANTICOKE HAND BASKETS AND CORNHUSK BASKET 

Millsboro are pointed out the remains of pits in the sandy hillside just above the ponds at the edge of the village. These pits are said to have been "wigwam pits." Without discussing this claim, one finds the village-sites nearer to the Indian settlement about six miles from Millsboro, close to a spot known locally as "Puddle Hole," much more interesting. Here quantities of arrowheads, hammerstones, lanceheads, knives, steatite objects, and quantities of a fine, stamped, pottery-ware are found upon the sandy surface of the soil. From this spot, beginning a few hundred yards and extending a mile or so eastward are remains of several shellheaps, the shells widely scattered over the surface, though not extending to any depth. These shell deposits, always near the bank, are of the shallowest sort, the soil being visible among the shells even where the latter are most abundant. Occasional artifacts are found in the midst of these spaces. The Indians say that the ancient people came to these places to have their oyster feasts. The bank has been washed away very much by the action of the river. In the memory of Mr Clark, one point in particular, where his grandmother's house stood, has been washed back more than fifty feet. Probably the camp-sites along the shore have suffered much from this cause.

Another more interesting site is a low mound situated about a mile and a half from the river, immediately bordering the road which leads to Georgetown, Delaware, fourteen miles away. This mound I estimated to be about I5 feet high and 40 paces in diameter. It is composed entirely of sand and is fairly discernible, though Mr Clark says that in his lifetime and that of his father it has worn down at least five feet. The mound now has upon it a growth of sturdy yellow pines. Mr Clark says that his father learned from the elders of the community, many years ago, that the mound was a repository for the dead in the days of the Indians. We might presume that this mound was the site of one of the mortuary houses of the Nanticoke. In excavating a pit near the center of the mound with Mr Clark, we came upon fragments of very old red brick and green-glass bottles which are said to have been sold with rum to the Indians by the early traders. 
TALES

For a rather large community there seems to be a dearth of tales having any local distinctiveness or dealing with the animal kingdom. The few rather colorless stories which repeated inquiry brought out are the following, some of which are widespread among both whites and negroes.

RABBIT AND FOX RAISE A CROP

One time a Rabbit and a Fox made arrangements to become partners in raising a crop. They got a piece of ground and set out to raise turnips. The Fox said he would take all that was above the ground for his share of the crop, and the Rabbit could have what was underneath the ground for his. So that year the Fox got only the turnip-tops, while the Rabbit got the turnips. Next year they entered into partnership again, and the Fox said that this time he would again have first choice. So he chose what grew beneath the ground for his share, and the Rabbit agreed to take what grew above. Then they planted their crop, and this time it was cabbage. When the crop was gathered, the Rabbit got all the best again and the Fox got nothing again. This is how he got fooled.

\section{ORIGIN OF DEAD WOOD}

One time Crane went down to the river to catch eels. When he got one, he swallowed it alive, but it came right through him and came out his other end. He caught the eel again, and he did the same, with the same result. And again. Then he backed up against a dead stump and swallowed him again, saying, "Now you devil, I've got the dead-wood on you." And the eel could not get through. That is the way, they say, dead wood first started.

\section{THE WREN OUTWITS THE EAGLE}

The Eagle was recognized as king of the birds, because he could fly higher than any others. But one time the little Wren said that he could go even higher than the Eagle. So they challenged him to prove it, and they began flying upward. Then the Wren perched himself upon the Eagle's back and stayed there until the Eagle 

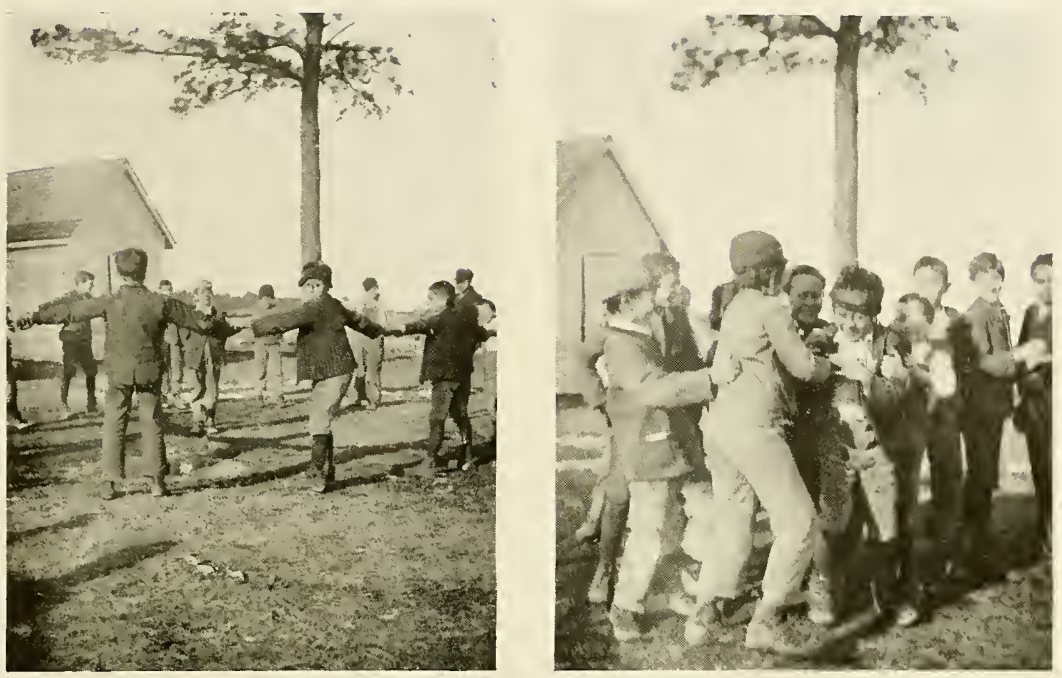

NANTICOKE CHILDREN PLAYING "BEAR-IN'-RING”,

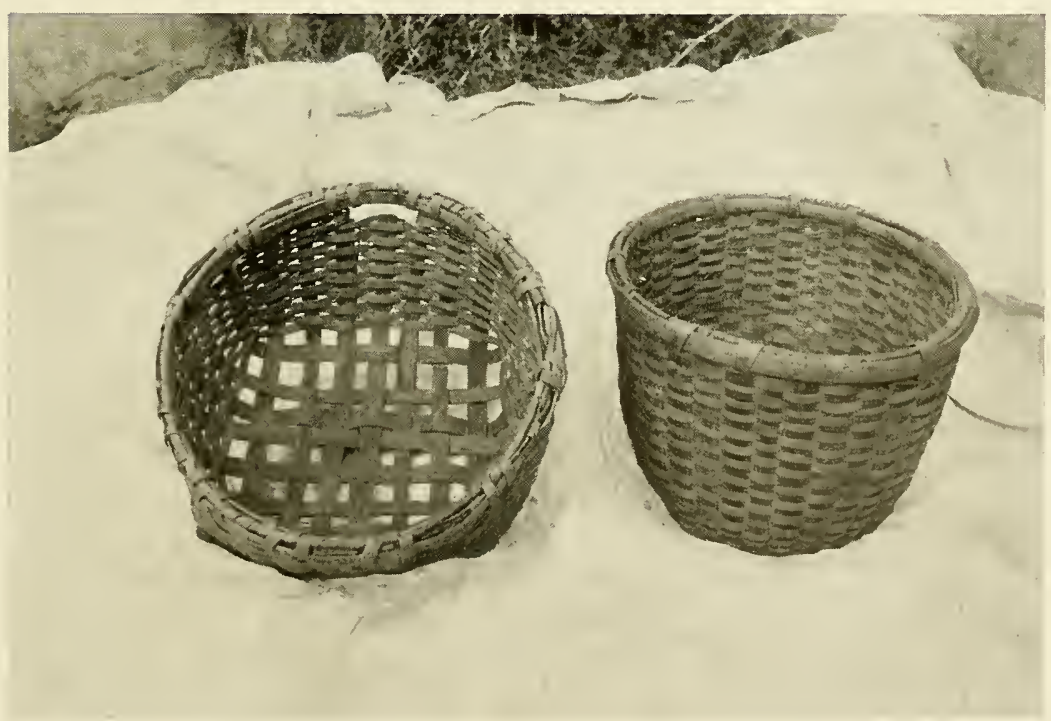

NANTICOKE FISH AND CORN BASKETS 

had flown as high as he was able. When they came down again the Wren declared that he had been higher than the Eagle, for as high as the eagle had gone, he had all the time been above him.

THE WONDERFUL HUNTER

There was once an old man and his wife who lived alone in the woods. One time they were all out of provisions, and he had only one bullet and one charge of powder for his gun. So he went hunting to see what luck he would have. Pretty soon, as he was going along, he saw a deer on his right. At his left, all in line upon the branch of a tree, he saw seven wild turkeys. At the same time he espied a rabbit directly in front of him, and a covey of quail behind him. So he took aim and shot his one bullet into the branch upon which the turkeys were sitting, splitting it, so that when it sprang together the seven turkeys were caught by the toes. At the same time the gun exploded, the barrel went backward, striking and killing the deer, the stock flew forward killing the rabbit, while the burst of the thing blew his coat off his back over the flock of quail. Now he had so much game that he didn't know what to do, so he hurried home to get something to carry it in. On the way home he jumped through the branch (stream) and caught his breeches full of perch. That is a hunter's story.

\section{A TERRAPIN FOR A WATCH ${ }^{1}$}

There was once an old fellow who met another going along the road. In those times they told the time of day by the sun. The old man asked the other about the time, and the other pulled a watch out of his pocket and told him, "Half past ten." The old man had never seen a watch before and thought it was a wonder. Pretty soon, as he went along, he found a terrapin. He thought it looked like the other's watch, so took it along with him, putting it in his shirt. After going a little way he met a woman, who asked him about the time. "Half past twelve and scratching like Hell!" he cried as he jerked the terrapin from his shirt.

${ }^{1}$ A version of the same tale is current among the Creek Indians, among whom I obtained it in text in Oklahoma. 
THE THREE QUESTIONS

There were once two Irish "terriers" who were brothers. One of them was offered a job by a wealthy man who promised him his pay if he would answer three questions that he would put to him. The Irishman accepted and agreed to come next day to hear the questions. When he went home and told his brother about it, his brother desired to go in his place. The next day, accordingly, the brother went in the other's place, and the man asked him, "How much does the moon weigh?" "One hundred pounds," answered the Irishman. "How do you know?" asked the man. "Because it has four quarters," was the answer. "Very well then, how many stars are there?" "A million. If you do not believe it, count them!" For the third question the man asked, "What am I thinking of?" "You think I am Pat, but I'm not, I'm Mike," was the reply. Having answered the three questions, Mike secured the job for Pat.

\section{The Local Dialect of English}

Since, at the instance of Dr Boas, studies of folk-communities in various parts of America are beginning to be considered of importance to ethnology, I shall append a list of vernacular terms in use among these people. There are, of course, many more idiomatic forms of speech than I could record. The dialect in general has so many local peculiarities that people from other parts of the Middle States often find it difficult at first to comprehend. The white people of Sussex county, moreover, do not have the same idiosyncrasies, as I have taken pains to observe, although those born in the immediate neighborhood of the Nanticoke-Moors do.

\section{Phonetic Peculiarities ${ }^{1}$}

Among the consonants $r$ is pronounced with the tongue tip well curved but with no trill. Final consonants have a tendency to be dropped, as mort, "mortar," org $\alpha$, "organ."

English ordinary $i(a i)$ and $a$ before $r$ are given the quality of

1 The characters recommended for American ethnologists by the Committee on Phonetics of the American Anthropological Association are used here. 


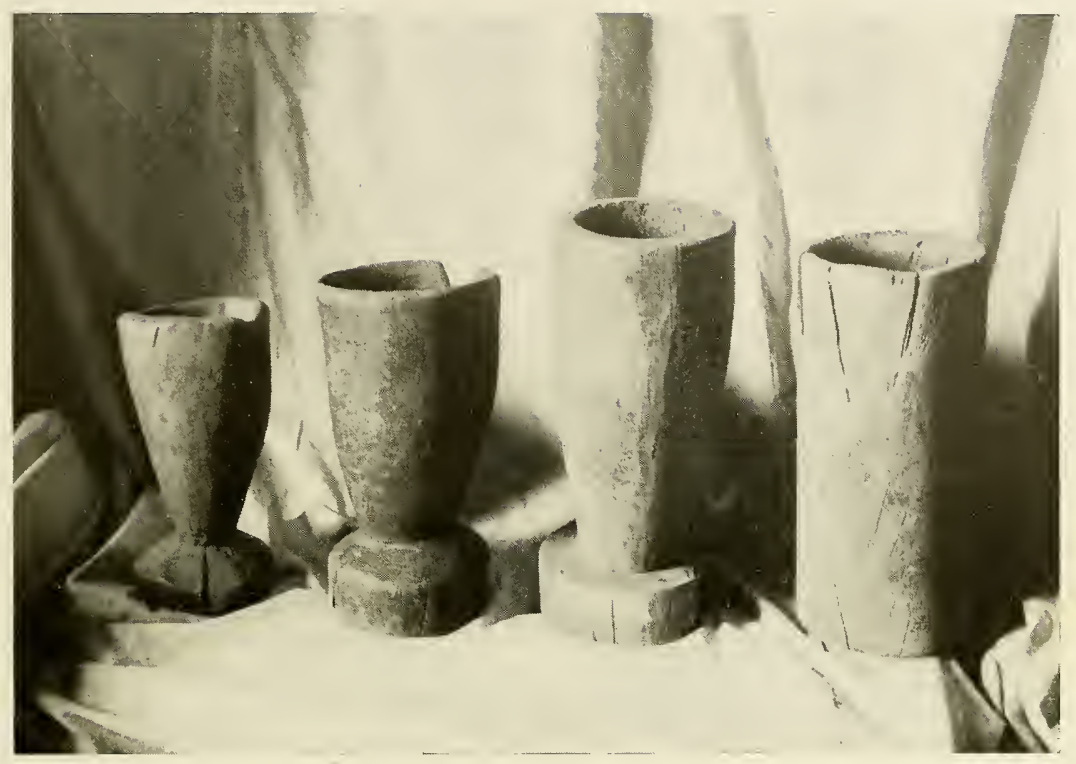

NANTICOKE COFFEE MORTARS

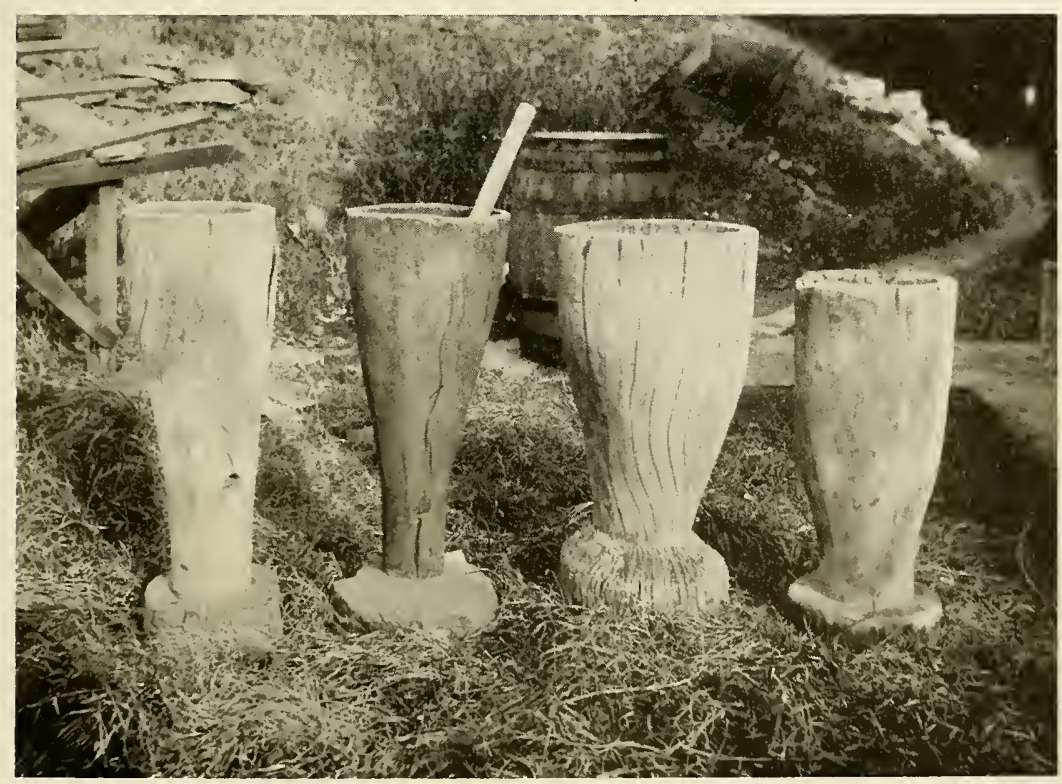

NANTICOKE CORN MORTARS 

$\jmath^{\circ}$, a close vowel almost like $a$ in fall; for example are is $\jmath^{\circ}$, sparrow is spor, fire is $f \jmath^{\circ} r$. The impure vowel $e a(r)$, as in heard, perch, and peart, is pronounced $i r$ ( $i$, long, as $e e$ in English queen), whence, pirtc "perch," pirrt "peart," hirrd "heard." Final $a(h)$ is often pronounced as $e$; Noah as "noe." Also -ere ("there, where") is pronounced - $\alpha r$ ("wh $\alpha \mathrm{r}$," etc.).

In vocabulary we observe the following local usages:

\section{NOUNS AND PRONOUNS}

mullet

mullein plant

mirkel

myrtle tree

sarsafäk

sassafras

$\mathrm{yu}^{\prime} \mathrm{po}$ 'n

wintergreen berry. (The yupon in the South is the name of Ilex cassine.)

tit spo'r

"tit sparrow," any small sparrow-English, chipping or song sparrow.

branch

a stream

puddle hole

a pond

savannah

pound

a swamp in the woods

the farmyard enclosure

ganzer

a woolen sweater

snouterbilly

cap that pulls down over the ears.

darts

pirogue

arrowheads

a dugout canoe

booby owl

barred owl

saddy

hit

thank you

it

foreparents

forefathers

meetin'

church

shets

nigh

pine needles (probably for "sheds")

this one, here

yon

that one, there

a settlement

fat lighter fat wood

resinous pine splints for starting a fire. 


\section{VERBS AND OTHER PARTS OF SPEECH}

to gear up ( $g \alpha \cdot \mathrm{r}$ )

to chunk

to work on

to over

out of

to get together

tarry

stir

kivver

peart (pirt)

pleasurin'

boat ridin'

to handle

studyin'

right

tolerable (toleb $\alpha \mathrm{l}$ )

make a light

to reckon

just like as if

mashed

to be fifteen out

proggin (pro ${ }^{\prime \prime} g \cdot$ in $)$

fusty

gettin' them worked on

slop the hogs

rest your hat

deviling'

beatenest

to see after

figgerin' to tie, harness, lace

to throw something, generally a piece of wood, at someone.

to tease, torment, to insist on

to get over, recover

descended from, belonging to

to prepare, to make

to linger

to hurry

to cover

to be in good health, lively

to be enjoying oneself, to seek pleasure.

to sail in a boat

to manage

worrying

very (right cold, "very cold")

quite

to light

to guess

just as though

bruised

more than fifteen years of age

to make a living on the river by fishing and canoeing

fussy, fretful

having work done on something

feed slops to the hogs

take off your hat (said to a caller)

to tease

worst

to look after, provide for

planning

Several interesting phrases characterize the community:

"Are you well?" (with a rising accent) is the common greeting between acquaintances. The phrase "on you," "on me," "on 
Isaac" in one sense denote "on your land," "on my land," "on Isaac's land," respectively.

Also "'mongst you" (amongst you) is used almost every time simply "you" as the subject of a verb is intended, as "Mongst you all done?" "Are you all done?" "Mongs' you comin'?" "Are you all coming?" "'Mongs' you got a dog (do'g)?" "Have you a dog?"

\section{Appendix}

In a letter to the writer, Dr Amandus Johnson, of the University of Pennsylvania, who has investigated extensively the history of the Swedes in Delaware, says: "A statement in Beskrifning om de svenska församlingars forna och närvarande tillstånd, by Acrelius [p. 308], may possibly add to the probability of the "Moor tradition.' Acrelius says that in $\mathbf{1} 745$ 'Spanish privateers tried to make a landing in the Delaware.' 1 It is quite likely that one of these vessels may have been wrecked on the Delaware coast at the time. I have seen a statement to this effect somewhere, but am unable to recall the source." Dr Johnson adds that the settlers at Fort Christiania (Wilmington) strengthened their fort at this time in anticipation of attack.

${ }^{1}$ On the beach at Lewestown, the old name for Lewes, Delaware, iron utensils of the colonial period are often found. These, the natives believe, are relics of the traditional shipwrecked crew. It is asserted that nearly all were saved at the time, and that they dwelt on the beach for awhile. 



\section{CONTRIBUTIONS}

FROM

\section{THE MUSEUM OF THE AMERICAN INDIAN HEYE FOUNDATION}

\section{CONTENTS OF VOLUME I}

I. Lucayan Artifacts from the Bahamas. THEODOOR DE BoOY.

2. Precolumbian Decoration of the Teeth in Ecuador, with some Account of the Occurrence of the Custom in Other Parts of North and South America. Marshall H. Saville.

3. Certain Kitchen-middens in Jamaica. THEODOOR DE BOOY.

4. Porto Rican Elbow-Stones in the Heye Museum, with Discussion of Similar Objects Elsewhere. J. WALTER FEWKES.

5. Note on the Archeology of Chiriqui. George Grant MacCurdy.

6. Petroglyphs of Saint Vincent, British West Indies. THомas HUCKERBY.

7. Prehistoric Objects from a Shell-heap at Erin Bay, Trinidad.

J. WALter FeWkEs.

8. Relations of Aboriginal Culture and Environment in the Lesser Antilles. J. WALter Fewkes.

9. Pottery from Certain Caves in Eastern Santo Domingo, West Indies. THEODOOR DE BOOY. 
